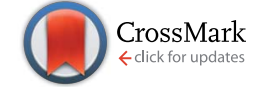

Cite this: RSC Adv., 2015, 5, 14747

Received 6th December 2014 Accepted 22nd January 2015

DOI: 10.1039/c4ra15905e

www.rsc.org/advances

\title{
Positive and negative allosteric effects of thiacalix[4]arene-based receptors having urea and crown-ether moieties $\uparrow$
}

\author{
Hirotsugu Tomiyasu, ${ }^{a}$ Jiang-Lin Zhao, ${ }^{a}$ Xin-Long Ni, ${ }^{b}$ Xi Zeng, ${ }^{b}$ Mark R. J. Elsegood, ${ }^{c}$ \\ Beth Jones, ${ }^{c}$ Carl Redshaw, ${ }^{d}$ Simon J. Teat ${ }^{e}$ and Takehiko Yamato*a
}

\begin{abstract}
Heteroditopic receptors $\left(4_{a-e}\right)$ based on a thiacalix[4]arene in the 1,3-alternate conformation, which have two urea moieties linking various phenyl groups substituted with either electron-donating or -withdrawing groups at their $m$-, or $p$-positions with a crown-ether moiety at the opposite side of the thiacalix[4]arene cavity, have been synthesized. The two examples with $p-\mathrm{CH}_{3}^{-}\left(4_{b}\right)$ and $p-\mathrm{NO}_{2}-$ substituted $\left(4_{e}\right)$ phenyl groups have been characterized by $X$-ray crystallography. The binding properties of receptor $4_{e}$ were investigated by means of ${ }^{1} \mathrm{H}$ NMR spectroscopic and absorption titration experiments in $\mathrm{CHCl}_{3}$-DMSO $(10: 1, \mathrm{v} / \mathrm{v})$ solution in the presence of $\mathrm{K}^{+}$ions and various anions. Interestingly, it was found that receptor $4_{e}$, which possesses two $p$-nitrophenyl ureido moieties, can complex most efficiently in the urea cavity or the crown-ether moiety; and the plausible allosteric effect of receptor $4_{\mathrm{e}}$ was also studied.
\end{abstract}

\section{Introduction}

The use of calix $[n]$ arenes $^{\mathbf{1}}$ as building blocks for receptors capable of the highly selective recognition of cations, anions or neutral molecules has received considerable attention in the field of supramolecular chemistry. Among the various kinds of calix $[n]$ arenes available, thiacalix[4] $\operatorname{arenes}^{2,3}$ are proving to be competent scaffolds and are finding wide use, for example as chemosensors, as well as in catalysis because of their favourable conformational properties, easy functionalization and emerging metal coordination chemistry. Several kinds of systems based on thiacalix[4]arenes are suitable for allosteric regulation $^{4}$ of host-guest interactions with metal cations, and these contribute greatly to organic processes in biological systems. Anions also play an important role in biological processes, and are closely related with biological systems such as DNA and enzyme substrates. The development and the investigation of anion selective sensors $^{5}$ have attracted

${ }^{a}$ Department of Applied Chemistry, Faculty of Science and Engineering, Saga University, Honjo-machi 1, Saga 840-8502, Japan. E-mail: yamatot@cc.saga-u.ac.jp ${ }^{b}$ Key Laboratory of Macrocyclic and Supramolecular Chemistry of Guizhou Province, Guizhou University, Guiyang, Guizhou, 550025, China

${ }^{c}$ Chemistry Department, Loughborough University, Loughborough LE11 3TU, UK

${ }^{d}$ Department of Chemistry, The University of Hull, HU6 7RX, UK

${ }^{e} A L S$, Berkeley Lab, 1 Cyclotron Road, Bereleley, CA 94720, USA

$\dagger$ Electronic supplementary information (ESI) available: Details of the ${ }^{1} \mathrm{H} /{ }^{13} \mathrm{C}$ NMR spectra, ${ }^{1} \mathrm{H}$ NMR spectroscopic and UV-vis titration experimental data, the Bensei-Hilderbrand plot and Job's plot. CCDC 1026081 and 1026090. For ESI and crystallographic data in CIF or other electronic format see DOI: 10.1039/c4ra15905e considerable interest. However, it is more difficult to accomplish compared with metal cation sensors because anions can possess structures of different shapes, ${ }^{6}$ typically spherical $\left(\mathrm{F}^{-}, \mathrm{Cl}^{-}, \mathrm{Br}^{-}, \mathrm{I}^{-}\right)$, Y-shaped $\left(\mathrm{AcO}^{-}, \mathrm{PhCOO}^{-}\right)$or tetrahedral $\left(\mathrm{H}_{2} \mathrm{PO}_{4}{ }^{-}\right)$. In recent years, anion receptors based on calix $[n]$ arenes have become an active research topic. Calix$[n]$ arene urea derivatives are efficient for anion recognition given the hydrogen-bonding interaction between anions and $\mathrm{N}-\mathrm{H}$ protons which can occur.

Colorimetric chemosensors ${ }^{7,8}$ have also attracted attention due to some desirable features such as easy detection by the naked eye, construction of simple, low-cost devices and so on. Many colorimetric anion receptors containing a variety of chromogenic signaling units such as indole, imidazolium, benzenediimide, 4-nitrophenylazo, diazo and anthraquinone groups have been developed. Furthermore, numerous colorimetric anion sensors utilizing a variety of structural scaffolds, which contain urea groups, have been investigated and proved to be efficient naked-eye detectors for various anions. However, there are a few reports on the development of colorimetric chemosensors based calix[4] arene type scaffolds. ${ }^{8 l, p}$

Lhoták ${ }^{9}$ and co-workers have reported anion receptors based on either an upper rim substituted calix[4]arene or thiacalix[4]-arene, which contains two $p$-nitrophenyl or $p$-tolyl ureido moieties. ${ }^{\mathbf{9}-\boldsymbol{c}, \boldsymbol{h}}$ These anion receptors exhibited effective recognition abilities towards selected anions in common organic solvents. Moreover, Kumar $^{10}$ and co-workers reported an anion receptor bearing a calix[4] arene in the 1,3-alternate conformation, which contains two p-nitrophenyl moieties..$^{10 g}$ This compound exhibited strong binding and good selectivity for $\mathrm{Cl}^{-}$ion due to the formation of 
strong hydrogen bonds between the $\mathrm{Cl}^{-}$ion and $\mathrm{N}-\mathrm{H}$ protons in common organic solvents. However, investigations concerning the appearance of an allosteric effect in analogues based on the interaction of thiacalix[4] arene and alkali metal cations and anions has not yet been reported.

Herein, we have independently designed a heterodimeric system $^{\mathbf{1 1}}$ based on a thiacalix[4] arene having two different side arms, viz two ureas moieties linking various phenyl groups bearing either electron-donating or -withdrawing groups at their $m$-, or $p$-positions. The calixarene also has a crown ether moiety at the opposite side of the thiacalix[4]arene cavity. We herein put forward the hypothesis (and then demonstrate) that the heterodimeric system, which is controlled by the complexation of the opposing side arms with anions and $\mathrm{K}^{+}$ion, exhibits effective positive and negative allosteric effects.

\section{Results and discussions}

\section{Synthesis}

The $O$-alkylation of distal-1 was carried out with 1.5 equivalents of tetraethyleneglycol ditosylate in the presence of an equivalent of $\mathrm{K}_{2} \mathrm{CO}_{3}$ according to the reported procedure, and afforded the desired 1,3-alternate-2 in $83 \%$ yield. ${ }^{12}$ The hydrazinolysis of 1,3-alternate-2 was carried out with a large excess of hydrazine hydrate, and afforded the desired 1,3-alternate-3 in $86 \%$ yield. The condensation of 1,3-alternate-3 with 2.2 equivalents of the appropriate isocyanate in THF furnished the receptors $\mathbf{4}_{\mathbf{a}-\mathbf{e}}$ in good to excellent yields (Scheme 1). In general, the ${ }^{1} \mathrm{H}$ NMR spectrum of receptors $\mathbf{4}_{\mathbf{a}-\mathbf{e}}$ in $\mathrm{CDCl}_{3}-\mathrm{DMSO}(10: 1, \mathrm{v} / \mathrm{v})$ exhibited the characteristics of a 1,3-alternate conformation such as two singlets $(18 \mathrm{H}$ each) for the tert-butyl protons, one singlet $(4 \mathrm{H})$ for $\mathrm{OCH}_{2} \mathrm{CO}$ protons, two singlets $(4 \mathrm{H}$ each) for aromatic protons and two singlets $(2 \mathrm{H}$ each) for four urea $\mathrm{NH}$ protons.

The molecular structures of receptors $\mathbf{4}_{\mathbf{b}}$ and $\mathbf{4}_{\mathbf{e}}$ were also verified by X-ray crystallographic analysis (Fig. 1 and S15 and S16 $\dagger^{\dagger}$ ). Receptors $\mathbf{4}_{b}$ and $\mathbf{4}_{\mathbf{e}}$ were recrystallized from a mixture of $\mathrm{CHCl}_{3}-\mathrm{CH}_{3} \mathrm{CN}(1: 1, \mathrm{v} / \mathrm{v})$ by slow evaporation. These results indicate that receptors $\mathbf{4}_{\mathbf{b}}$ and $\mathbf{4}_{\mathbf{e}}$ adopt the 1,3-alternate
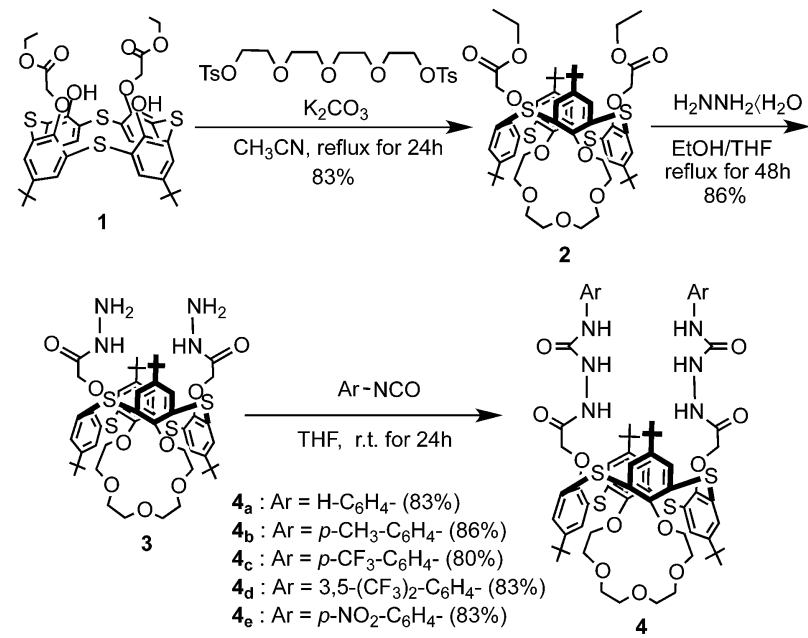

Scheme 1 Synthesis of receptors 1,3 -alternate- $4_{a-e}$ a) $0(23)$
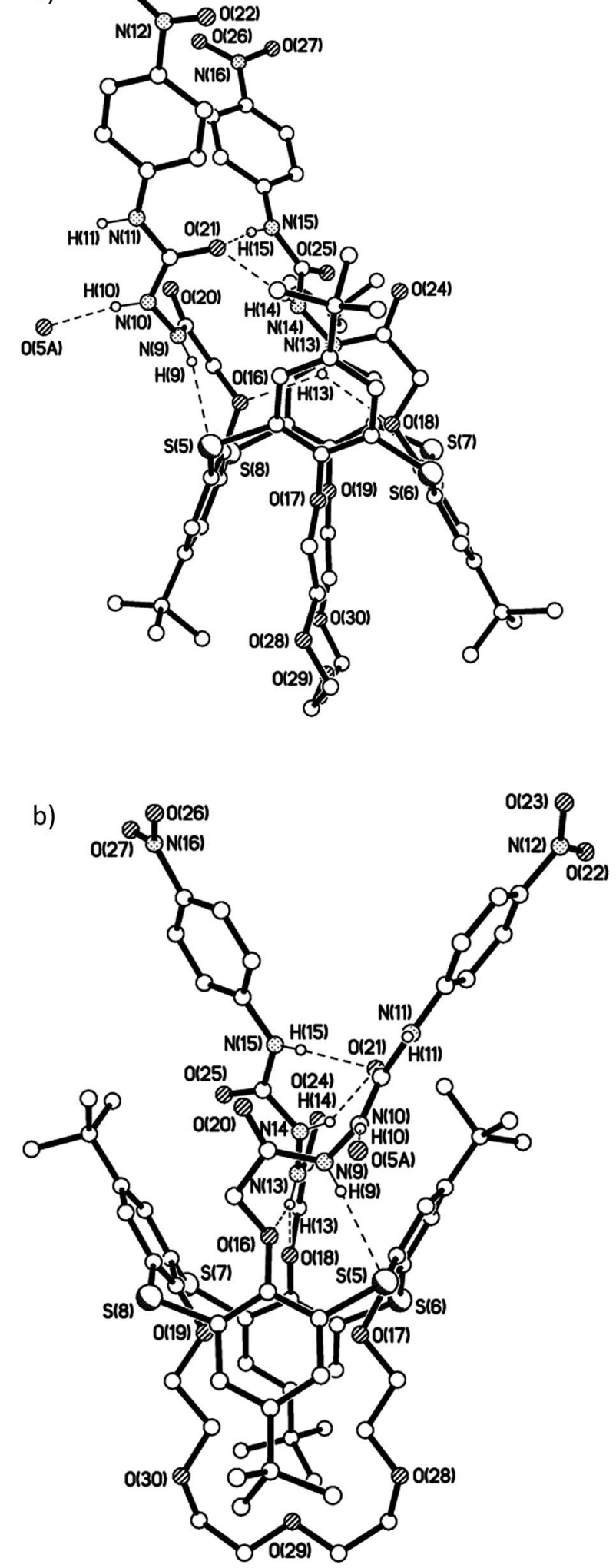

Fig. 1 X-ray crystal structure of receptor $4 \mathrm{e}$. $\mathrm{H}$-bonds shown as dashed lines. One of two similar molecules in the asymmetric unit is shown in two orientations rotated by approx. $90^{\circ}$. $\mathrm{H}$ atoms not involved in $\mathrm{H}$-bonding, minor disorder components, and chloroform molecules of crystallization are omitted for clarity. 
Table 1 Association constants of receptor $4_{\mathrm{a}-\mathrm{e}}$ with $\mathrm{Cl}^{-}$ions ${ }^{a, b}$

\begin{tabular}{lllll}
\hline Host & $\mathbf{4}_{\mathbf{a}}$ & $\mathbf{4}_{\mathbf{b}}$ & $\mathbf{4}_{\mathbf{c}}$ & $\mathbf{4}_{\mathbf{d}}$ \\
$\mathrm{R}$ & $\mathrm{H}$ & $p-\mathrm{CH}_{3}$ & $p-\mathrm{CF}_{3}$ & $3,5-\left(\mathrm{CF}_{3}\right)_{2}$ \\
$K_{\mathrm{a}}\left[\mathrm{M}^{-1}\right]$ & $6816 \pm 545$ & $3021 \pm 242$ & $12813 \pm 1025$ & $6945 \pm 625$
\end{tabular}

${ }^{a}$ Measured in $\mathrm{CDCl}_{3}-\mathrm{DMSO}(10: 1, \mathrm{v} / \mathrm{v})$ at $298 \mathrm{~K}$ by the ${ }^{1} \mathrm{H}$ NMR titration method using the chemical-shift change of the $\mathrm{NH}_{\mathrm{a}}$ proton (Fig. S17-S22); host concentration was $4.0 \times 10^{-3} \mathrm{M}{ }^{b}$ Guests used: $\mathrm{Bu}_{4} \mathrm{NCl}$.

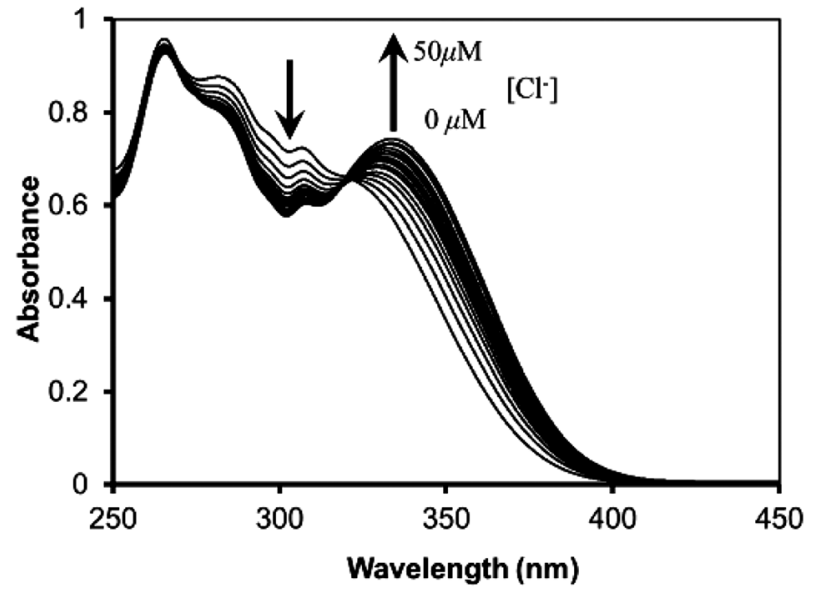

Fig. 2 UV-vis absorption spectra of receptor $4_{\mathrm{e}}(2.5 \mu \mathrm{M})$ upon the addition of $\mathrm{Bu}_{4} \mathrm{NCl}(0-50 \mu \mathrm{M})$ in $\mathrm{CH}_{2} \mathrm{Cl}_{2}$-DMSO $(10: 1, \mathrm{v} / \mathrm{v})$.

conformation in the solid state. There are two thiacalixarenes, one water molecule and three chloroform molecules in the asymmetric unit. Interestingly, it was found that two urea groups approach each other and are oriented in parallel due to the existence of dual intramolecular hydrogen bonding (in case of receptor $4_{e}$, for the molecule shown: $\mathrm{N}(14)-\mathrm{H}(14) \cdots$ $\mathrm{O}(21) 2.37(2)$; $\mathrm{N}(15)-\mathrm{H}(15) \cdots \mathrm{O}(21) 2.05(2) \AA$; for the second molecule: $\mathrm{N}(2)-\mathrm{H}(2) \cdots \mathrm{O}(10) 2.37, \mathrm{~N}(3)-\mathrm{H}(3) \cdots \mathrm{O}(10) 1.94(2) \AA)$ (Fig. 1 and S16 $\dagger$ ). Moreover, the thiacalix[4]-arenemonocrown-5 has a three-dimentional cavity and is large enough to accommodate the metal cation. The association constants $\left(K_{\mathrm{a}}\right.$ values) between the receptors $\mathbf{4}_{\mathbf{a}-\mathbf{e}}$ and $\mathrm{Cl}^{-}$ion were determined by ${ }^{1} \mathrm{H}$ NMR spectroscopic titration experiments (Table 1). These results suggest that the association constants depend on the electron-donating/withdrawing groups located at the $m-$, or $p$-positions. In the presence of the electronwithdrawing groups, such as $\mathrm{CF}_{3}$ (receptors $\mathbf{4}_{\mathbf{c}}$ and $\mathbf{4}_{\mathbf{d}}$ ) and $\mathrm{NO}_{2}$ (receptor $\mathbf{4}_{\mathbf{e}}$ ), the $K_{\mathrm{a}}$ values were greater than that for the unsubstituted receptor (receptor $\mathbf{4}_{\mathbf{a}}$ ). In contrast, in the case of receptor $\mathbf{4}_{\mathbf{b}}$, possessing the electron-donating Me group, there was a general decrease in the $K_{\mathrm{a}}$ value upon complexation with $\mathrm{Cl}^{-}$ion in comparison with the unsubstituted receptor $\mathbf{4}_{\mathbf{a}}$. Therefore, the introduction of electron-withdrawing groups at the $m$-, or $p$-positions appears to increase the acidity of the urea protons, and hence enhance the anion-binding ability through hydrogen-bonding interactions. The $K_{\mathrm{a}}$ value of receptor $\mathbf{4}_{\mathbf{e}}$ with the electron-withdrawing $\mathrm{NO}_{2}$ group at the $p$-position was the best out of all the $K_{\mathrm{a}}$ values measured for receptors $\mathbf{4}_{\mathrm{a}-\mathrm{e}}$ and $\mathrm{Cl}^{-}$ ion. Interestingly, it was found that the $K_{\mathrm{a}}$ value of receptor $\mathbf{4}_{\mathrm{c}}$

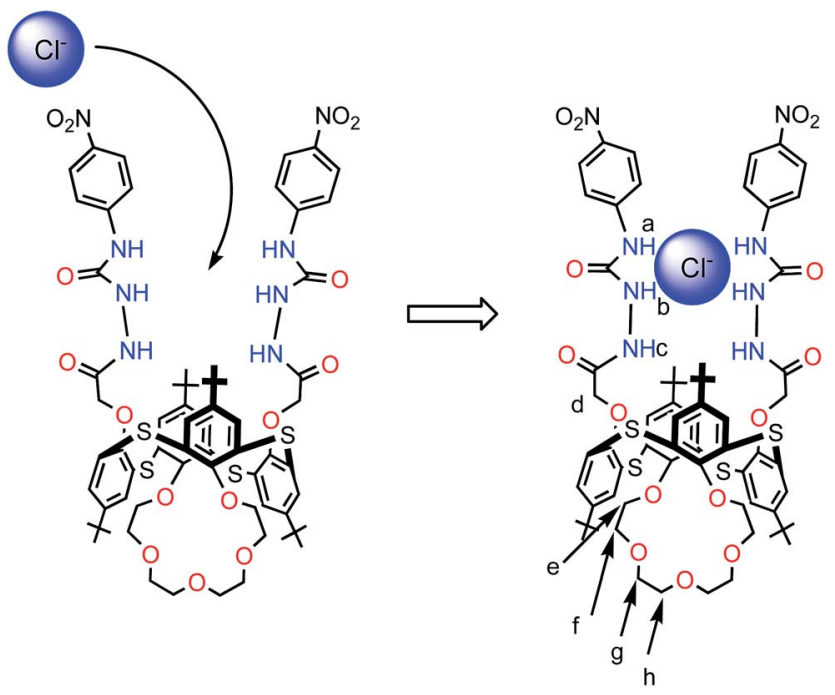

Fig. 3 Binding mode of receptor 4 upon complexation with $\mathrm{Cl}^{-}$ions.

with the electron-withdrawing $\mathrm{CF}_{3}$ group at the $p$-position was greater than that of receptor $\mathbf{4}_{\mathbf{d}}$ with the electron-withdrawing $\mathrm{CF}_{3}$ group at the $m$-position. This result indicates that electron-withdrawing groups located at the $p$-position can significantly influence the acidity of the urea protons by conjugating with the phenyl groups. From the above, it is clear that receptor $\mathbf{4}_{\mathbf{e}}$ with the electron-withdrawing $\mathrm{NO}_{2}$ group at the $p$-position has the most effective recognition ability toward selected anions. Given this, further complexation studies of receptor $\mathbf{4}_{\mathbf{e}}(2.5 \mu \mathrm{M})$ exhibits an absorption band at $310 \mathrm{~nm}$ in the UV spectrum in the absence of anions. Upon addition of $\mathrm{Cl}^{-}$ ion $(0-50 \mu \mathrm{M})$ to the solution of receptor $4_{e}$, Fig. 2 reveals a gradual decrease in the absorption of the band at $310 \mathrm{~nm}$ with a simultaneous increase in the absorption at $340 \mathrm{~nm}$. Meanwhile, a clear isosbestic point was observed at $322 \mathrm{~nm}$ for the receptor $\mathbf{4}_{\mathrm{e}}$. A Job's plot binding between the receptor $\mathbf{4}_{\mathrm{e}}$ and $\mathrm{Cl}^{-}$ion reveals a $1: 1$ stoichiometry (Fig. S25†), whilst the association constant $\left(K_{\mathrm{a}}\right.$ value) for the complexation with $\mathrm{Cl}^{-}$ion by receptor $\mathbf{4}_{\mathrm{e}}$ was determined to be $34152 \mathrm{M}^{-1}$ by UV-vis titration experiments in $\mathrm{CHCl}_{3}$-DMSO (10:1, v/v) (Fig. S24, S27-S31†). Moreover, the concentration dependence of the ${ }^{1} \mathrm{H}$ NMR chemical shifts of the ureido protons in receptor $\mathbf{4}_{\mathbf{e}}$ was not observed (Fig. S23†). This result suggests that receptor $\mathbf{4}_{\mathbf{e}}$ has a strong intramolecular hydrogen bond between the two ureas linking the $p$-nitrophenyl moieties. These results strongly suggested that $\mathrm{Cl}^{-}$ion recognition by receptor $\mathbf{4}_{\mathrm{e}}$ was via a hydrogenbonding interaction between the $\mathrm{Cl}^{-}$ion and $\mathrm{N}-\mathrm{H}$ protons as 
Table 2 Association constants of receptor $4 \mathrm{e}$ with various anions ${ }^{a, b}$

\begin{tabular}{|c|c|c|c|c|c|c|c|}
\hline Anion & $\mathrm{F}^{-}$ & $\mathrm{Cl}^{-}$ & $\mathrm{Br}^{-}$ & $\mathrm{I}^{-}$ & $\mathrm{AcO}^{-}$ & $\mathrm{PhCO}_{2}{ }^{-}$ & $\mathrm{H}_{2} \mathrm{PO}_{4}^{-}$ \\
\hline Shape & Spherical & Spherical & Spherical & Spherical & Y-shape & Y-shape & Tetrahedral \\
\hline$K_{\mathrm{a}}\left[\mathrm{M}^{-1}\right]$ & $128775 \pm 10302$ & $34152 \pm 2732$ & $7296 \pm 584$ & $4540 \pm 363$ & $107298 \pm 8584$ & $106743 \pm 8539$ & $108687 \pm 8695$ \\
\hline
\end{tabular}

${ }^{a}$ Measured in $\mathrm{CH}_{2} \mathrm{Cl}_{2}-\mathrm{DMSO}(10: 1, \mathrm{v} / \mathrm{v})$ at $298 \mathrm{~K}$ by UV-vis titration method (Fig. 2, 4, S24 and S27-S31); host concentration was $2.5 \mu \mathrm{M}$. ${ }^{b}$ Guests used: tetrabutylammonium salt.

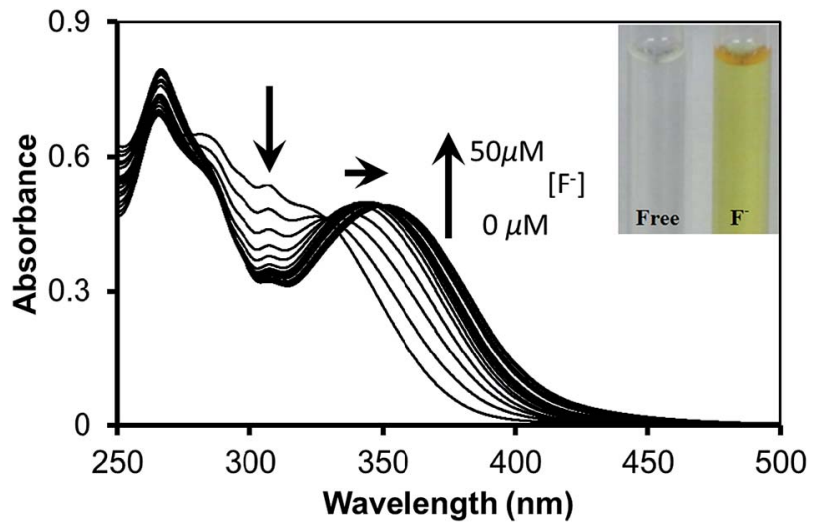

Fig. 4 UV-vis absorption spectra of receptor $4_{e}(2.5 \mu \mathrm{M})$ upon the addition of $\mathrm{Bu}_{4} \mathrm{NF}(0-50 \mu \mathrm{M})$ in $\mathrm{CH}_{2} \mathrm{Cl}_{2}-\mathrm{DMSO}(10: 1, \mathrm{v} / \mathrm{v})$.

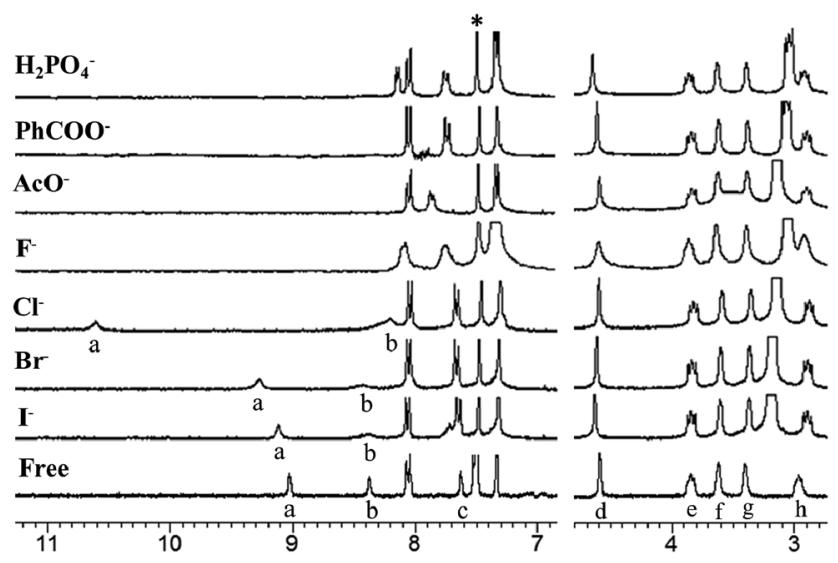

Fig. 5 Partial ${ }^{1} H$ NMR spectra of receptor $4_{e}$ /guest $(H / G=1: 1)$; free receptor $4_{e}$ and in the presence of 1 equiv. of $\mathrm{Bu}_{4} \mathrm{NX}(X=\mathrm{F}, \mathrm{Cl}, \mathrm{Br}, \mathrm{l}$, $\left.\mathrm{AcO}, \mathrm{PhCOO}, \mathrm{H}_{2} \mathrm{PO}_{4}\right)$. Host concentration was $2.5 \mu \mathrm{M}$. Solvent: $\mathrm{CDCl}_{3}$-DMSO $(10: 1, \mathrm{v} / \mathrm{v}) .300 \mathrm{MHz}$ at $298 \mathrm{~K}$. *Denotes the solvent peak.

shown in Fig. 3. Similarly, the UV-vis titration experiments of receptor $\mathbf{4}_{\mathbf{e}}$ with other various anions besides $\mathrm{Cl}^{-}$ion were carried out, and the $K_{\mathrm{a}}$ values are summarized in Table 2. As a result, it was found that receptor $\mathbf{4}_{\mathbf{e}}$ exhibited high selectivity towards $\mathrm{F}^{-}$ion amongst all of the anions tested, and was capable of complexing with all of the anions tested, irrespective of their shape. Interestingly, the color of the receptor $\mathbf{4}_{\mathbf{e}}$ solution changed from colorless to dark yellow upon addition of $\mathrm{F}^{-}$ion $(5$ equivalents), and this could be easily observed by the naked eye. Upon the addition of $\mathrm{F}^{-}$ions $(0-50 \mu \mathrm{M})$ to the solution of the
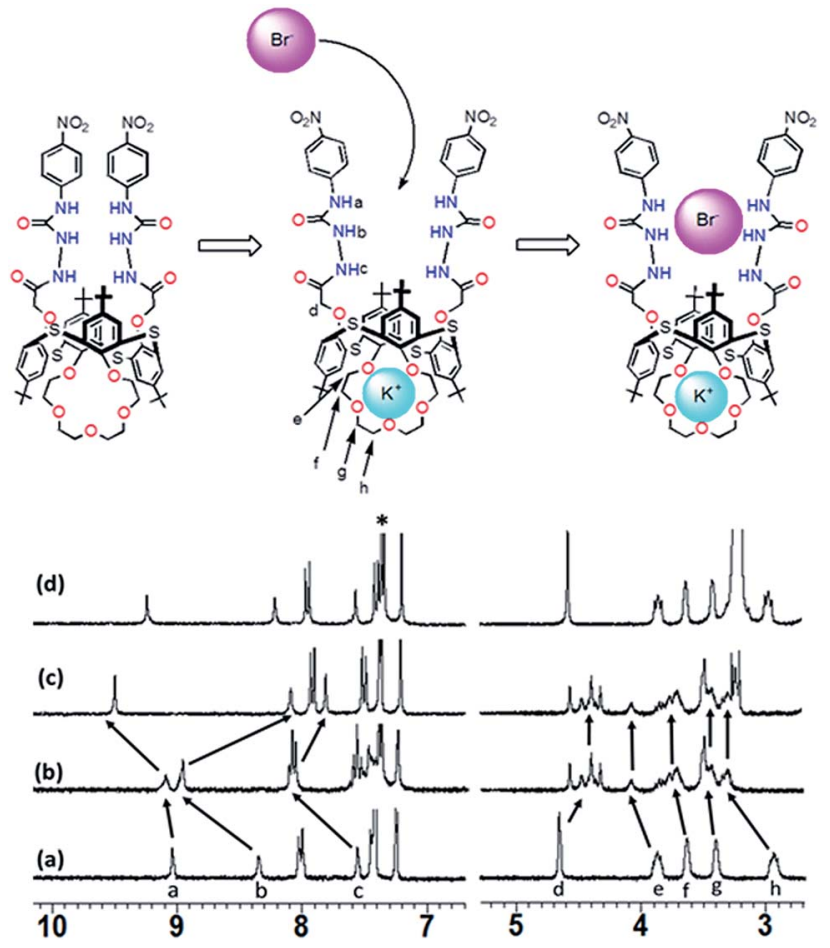

Fig. 6 Proposed positive allosteric behaviour of receptor $4_{e}$ with $\mathrm{Br}^{-}$ and $\mathrm{K}^{+}$ions. Partial ${ }^{1} \mathrm{H}$ NMR spectra of $4_{\mathrm{e}}$ /guest $(H / G=1: 1)$; (a) free $4_{e}$; (b) $4_{\mathrm{e}} \supset \mathrm{KSO}_{3} \mathrm{CF}_{3}$; (c) $\mathrm{Bu}_{4} \mathrm{NBr} \subset\left[4 \mathrm{e} \supset \mathrm{K}^{+}\right]$; (d) $4_{\mathrm{e}} \supset \mathrm{Bu}_{4} \mathrm{NBr}$. Solvent: $\mathrm{CDCl}_{3}$-DMSO $(10: 1, \mathrm{v} / \mathrm{v}) .300 \mathrm{MHz}$ at $298 \mathrm{~K}$. *Denotes the solvent peak.

receptor $\mathbf{4}_{\mathrm{e}}$, the absorption peak at $342 \mathrm{~nm}$ gradually moved to a longer wavelength, finally reaching a maximum value at $360 \mathrm{~nm}$ (Fig. 4 and S26†). This result suggests that the quinoid structure was formed by the deprotonation of urea $\mathrm{NH}$ groups in the $p$ nitrophenyl ureido moiety. Moreover, the addition of $\mathrm{F}^{-}, \mathrm{AcO}^{-}$, $\mathrm{PhCOO}^{-}$or $\mathrm{H}_{2} \mathrm{PO}_{4}^{-}$(1 equivalent) to solutions of receptor $\mathbf{4}_{\mathbf{e}}$ in $\mathrm{CHCl}_{3}$-DMSO $(10: 1, \mathrm{v} / \mathrm{v})$ during the ${ }^{1} \mathrm{H}$ NMR titration experiments resulted in the disappearance of the urea proton signals, $\mathrm{NH}_{\mathrm{a}}$ and $\mathrm{NH}_{\mathrm{b}}$ (Fig. 5). These results indicate that strong interactions between these anions and the urea $\mathrm{NH}$ groups in the receptor $\mathbf{4}_{\mathbf{e}}$ occur and that the kinetics of these anion exchanges is on the NMR time scale. On the other hand, ${ }^{1} \mathrm{H}$ NMR spectroscopic and UV-vis titration experiments of receptor $\mathbf{4}_{\mathbf{e}}$ with $\mathrm{K}^{+}$ ion at the crown-ether moiety were also carried out (Fig. S32 and S33†). When only $\mathrm{K}^{+}$ion ( 1 equivalent) were added, not only the downfield shift of the crown-ether bridge protons was observed, but also all the NH protons in ${ }^{1} \mathrm{H}$ NMR titration experiments (Fig. 6b and 7b). It was found that a Job's plot binding between 

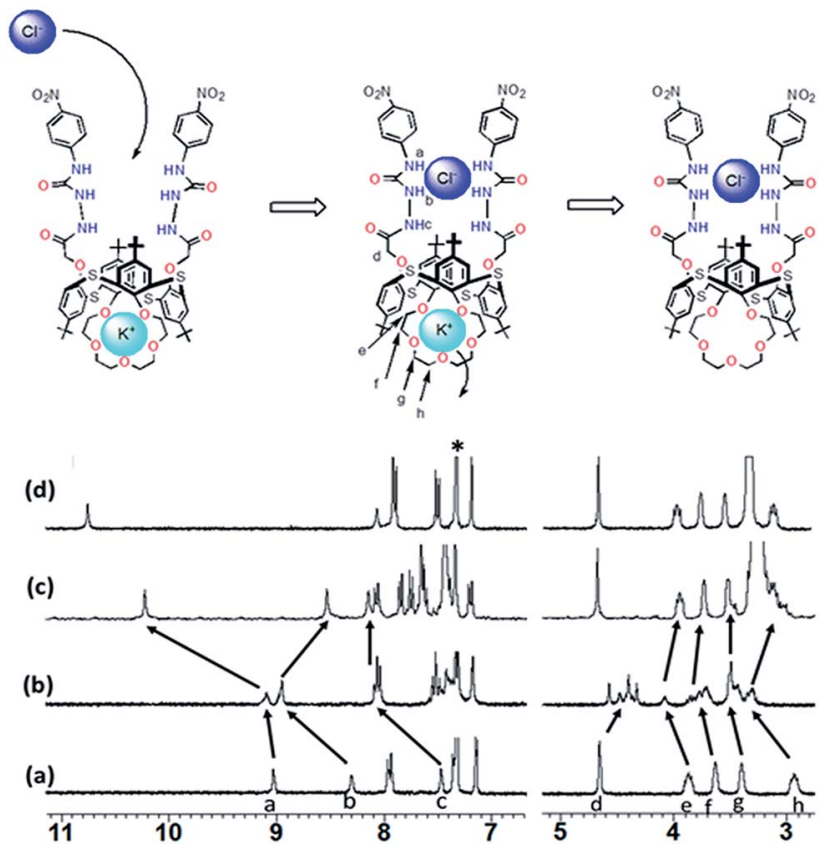

Fig. 7 Proposed negative allosteric behaviour of $4_{e}$ with $\mathrm{Cl}^{-}$and $\mathrm{K}^{+}$ions. Partial ${ }^{1} \mathrm{H}$ NMR spectra of $4_{\mathrm{e}}$ /guest $(H / G=1: 1)$; (a) free $4_{\mathrm{e}} ;(\mathrm{b})$ $4_{\mathrm{e}} \supset \mathrm{KSO}_{3} \mathrm{CF}_{3}$; (c) $\mathrm{Bu}_{4} \mathrm{NCl} \subset\left[4_{\mathrm{e}} \supset \mathrm{K}^{+}\right]$; (d) $4_{\mathrm{e}} \supset \mathrm{Bu}_{4} \mathrm{NCl}$. Solvent: $\mathrm{CDCl}_{3}-$ DMSO $(10: 1, v / v) .300 \mathrm{MHz}$ at $298 \mathrm{~K}$. *Denotes the solvent peak.

receptor $\mathbf{4}_{\mathrm{e}}$ and $\mathrm{K}^{+}$ion exhibited a $1: 1$ stoichiometry and that the $K_{\mathrm{a}}$ value for the complexation with $\mathrm{K}^{+}$ion was determined to be $28536( \pm 1998) \mathbf{M}^{-1}$ by UV-vis titration experiments in $\mathrm{CH}_{2} \mathrm{Cl}_{2}$-DMSO (10:1, v/v) (Fig. S34 and S35 $\dagger$ ). These results suggest that the crown- 5 ring of receptor $\mathbf{4}_{\mathbf{e}}$ binds $\mathrm{K}^{+}$ion. To seek more detailed information about the presence of an effective positive or negative allosteric effect between receptor $\mathbf{4}_{\mathbf{e}} \cdot \mathrm{K}^{+}$and $\mathrm{Br}^{-}$or $\mathrm{Cl}^{-}$ions, ${ }^{1} \mathrm{H}$ NMR spectroscopic and UV-vis titration experiments in $\mathrm{CHCl}_{3}$-DMSO (10:1, v/v) (Fig. S36†) were carried. Fig. 6 reveals that when $\mathrm{Br}^{-}$ion were added to the solution of $\left[\mathbf{4}_{\mathbf{e}} \supset \mathrm{KSO}_{3} \mathrm{CF}_{3}\right]$ (Fig. 6c), the addition induces a downfield shift of $0.42 \mathrm{ppm}(\delta=9.09$ to $9.51 \mathrm{ppm})$ for the $\mathrm{NH}_{\mathrm{a}}$ protons, and upfield shifts of $0.85 \mathrm{ppm}(\delta=8.95$ to $8.10 \mathrm{ppm})$ for the $\mathrm{NH}_{\mathrm{b}}$ protons and of $0.29 \mathrm{ppm}(\delta=8.10$ to $7.81 \mathrm{ppm})$ for the $\mathrm{NH}_{\mathrm{c}}$ protons, while the chemical shifts for the crown-ether bridge protons did not change. These results suggested the formation of a heteroditopic dinuclear complex of the type $\mathrm{Br}^{-} \subset\left[\mathbf{4}_{\mathbf{e}} \supset \mathrm{K}^{+}\right]$(Fig. 6c), and we propose a positive allosteric effect of receptor $\mathbf{4}_{\mathbf{e}}$ towards $\mathrm{Br}^{-}$ions in the presence of $\mathrm{K}^{+}$ion by an ion-pair electrostatic interaction and a conformational change of the flexible thiacalix[4]arene cavity as shown in Fig. 6. On the other hand, Fig. 7 shows that when $\mathrm{Cl}^{-}$ions were added to the solution of $\left[\mathbf{4}_{\mathbf{e}} \supset \mathrm{KSO}_{3} \mathrm{CF}_{3}\right]$ (Fig. 7c), this addition induces a downfield shift of $1.11 \mathrm{ppm}(\delta=9.09$ to $10.2 \mathrm{ppm})$ for the $\mathrm{NH}_{\mathrm{a}}$ protons and $0.04 \mathrm{ppm}(\delta=8.10$ to $8.14 \mathrm{ppm})$ for the $\mathrm{NH}_{\mathrm{c}}$ protons, and an upfield shift of $0.37 \mathrm{ppm}(\delta=8.95$ to 8.58 ppm) for the $\mathrm{NH}_{\mathrm{b}}$ protons, together with upfield shifts for the crown-ether bridge protons. Interestingly, when $\mathrm{Cl}^{-}$ions were added to the solution of $\left[\mathbf{4}_{\mathbf{e}} \supset \mathrm{KSO}_{3} \mathrm{CF}_{3}\right]$ (Fig. 7c), the chemical shifts for the crown-ether bridge protons most closely matched the chemical shifts for the free crown-ether bridge protons
(Fig. 7c and d). These results suggested that the two urea groups in two $p$-nitrophenyl ureido moieties of receptor $\mathbf{4}_{\mathbf{e}} \cdot \mathrm{K}^{+}$bind the $\mathrm{Cl}^{-}$ion by an ion-pair electrostatic interaction and a conformational change of the flexible thiacalix[4]arene cavity. This induces the decomplexation of the $\mathrm{K}^{+}$ion from the crown- 5 ring of receptor $\mathbf{4}_{\mathbf{e}}$ because the $\mathrm{Cl}^{-}$ion has a smaller ionic radius and therefore an increase in basicity in comparison with the $\mathrm{Br}^{-}$ion, and a negative allosteric effect of receptor $\mathbf{4}_{\mathbf{e}}$ to $\mathrm{Cl}^{-}$ion in the presence of $\mathrm{K}^{+}$ion as shown in Fig. 7 is proposed.

\section{Conclusion}

In summary, a new family of heteroditopic receptors $\left(\mathbf{4}_{\mathbf{a}-\mathbf{e}}\right)$ based on a thiacalix[4]arene in the 1,3-alternate conformation, which has two ureas moieties bearing various phenyl groups substituted with either electron-donating or -withdrawing groups at their $m$-, or $p$-positions, as well as a crown-ether moiety at the opposite side of thiacalix[4]arene cavity, has been synthesized. By using ${ }^{1} \mathrm{H}$ NMR spectroscopic and UV-vis titration experiments, receptor $\mathbf{4}_{\mathbf{e}}$ possessing an electronwithdrawing $\mathrm{NO}_{2}$ group at the $p$-position has the most effective recognition ability towards the selected anions. The binding of $\mathrm{K}^{+}$ions and various anions at the crown- 5 ring moiety and the two urea $\mathrm{NH}$ groups in two $p$-nitrophenyl ureido moieties, respectively, was investigated. The results indicated the complexation mode, and it was found that receptor $\mathbf{4}_{\mathbf{e}}$ was able to bind all of the anions tested, irrespective of their shape. Receptor $\mathbf{4}_{\mathbf{e}}$ exhibited highest selectivity towards $\mathrm{F}^{-}$ion amongst all of the anions tested and indicated that this receptor might be a promising candidate as a colorimetric chemosensor. The appearance of positive and negative allosteric effects in receptor $\mathbf{4}_{\mathbf{e}}$ was also investigated by ${ }^{1} \mathrm{H}$ NMR and UV-vis titration experiments. Interestingly, the formation of a heteroditopic dinuclear complex of receptor $\mathbf{4}_{\mathbf{e}}$ with $\mathrm{Br}^{-}$and $\mathrm{K}^{+}$ions by a positive allosteric effect could be observed. On the other hand, the fact that two urea $\mathrm{NH}$ groups in two $p$-nitrophenyl ureido moieties of receptor $\mathbf{4}_{\mathbf{e}} \cdot \mathrm{K}^{+}$bind the $\mathrm{Cl}^{-}$ion, which then induces the decomplexation of the $\mathrm{K}^{+}$ion from the crown-5 ring, is indicative of a negative allosteric effect.

\section{Experimental section}

\section{General}

All melting points were determined with Yanagimoto MP-S1. ${ }^{1} \mathrm{H}$ NMR spectra were determined at $300 \mathrm{MHz}$ with a Nippon Denshi JEOL FT-300 NMR spectrometer with $\mathrm{SiMe}_{4}$ as an internal reference; $J$-values are given in $\mathrm{Hz}$. UV spectra were measured by a Shimadzu 240 spectrophotometer. Mass spectra were obtained on a Nippon Denshi JMS-01SG-2 mass spectrometer at an ionization energy of $70 \mathrm{eV}$ using a direct inlet system through GLC. Elemental analyses were performed by Yanaco MT-5.

\section{Materials}

Unless otherwise stated, all other reagents used were purchased from commercial sources and used without further purification. 
Compounds $1^{13}$ and $2^{12}$ were prepared following the reported procedures.

\section{Synthesis of compound 3}

Compound $2(1.0 \mathrm{~g}, 0.95 \mathrm{mmol})$ was put into a round-bottom flask and ethanol $(120 \mathrm{~mL})$, THF $(120 \mathrm{~mL})$ and hydrazine hydrate $(14 \mathrm{~mL}$, large excess) were added and refluxed for $48 \mathrm{~h}$. After cooling, the solvents and excess hydrazine were removed under reduced pressure to give the crude product as a white solid. The residue was triturated sequentially with water and methanol and the product collected by filtration. Compound 3 was obtained $0.84 \mathrm{~g}(86 \%)$ as a white solid. M.p. $216-218^{\circ} \mathrm{C}$. IR: $\nu_{\max }(\mathrm{KBr}) / \mathrm{cm}^{-1}: 3421,2961,1670,1438,1263,1091,1019$ and 801. ${ }^{1} \mathrm{H}$ NMR $\left(300 \mathrm{MHz}, \mathrm{CDCl}_{3}\right): \delta=1.25(18 \mathrm{H}, \mathrm{s}, t \mathrm{Bu} \times 2), 1.37$ $(18 \mathrm{H}, \mathrm{s}, t \mathrm{Bu} \times 2), 3.00\left(4 \mathrm{H}, \mathrm{t}, J=9.1 \mathrm{~Hz}, \mathrm{OCH}_{2} \times 2\right), 3.39(4 \mathrm{H}, \mathrm{br}$, $\left.\mathrm{OCH}_{2} \times 2\right), 3.48\left(4 \mathrm{H}, \mathrm{br}, \mathrm{NH}_{2} \times 2\right), 3.60\left(4 \mathrm{H}\right.$, broad s, $\left.\mathrm{OCH}_{2} \times 2\right)$, $3.96\left(4 \mathrm{H}, \mathrm{t}, J=9.1 \mathrm{~Hz}, \mathrm{OCH}_{2} \times 2\right), 4.55\left(4 \mathrm{H}, \mathrm{s}, \mathrm{OCH}_{2} \mathrm{CO} \times 2\right)$, $7.35(4 \mathrm{H}, \mathrm{s}, \mathrm{Ar}-H \times 2), 7.41(4 \mathrm{H}, \mathrm{s}, \mathrm{Ar}-H \times 2)$ and $7.54(2 \mathrm{H}, \mathrm{s}, \mathrm{N} H$ $\times 2)$ ppm. ${ }^{13} \mathrm{C}$ NMR $\left(100 \mathrm{MHz}, \mathrm{CDCl}_{3}\right): \delta=30.5\left(\mathrm{CH}_{3}\right), 33.5$ $\left(\mathrm{C}\left(\mathrm{CH}_{3}\right)_{3}\right), 64.9\left(\mathrm{OCH}_{2}\right), 67.4\left(\mathrm{OCH}_{2}\right), 69.2\left(\mathrm{OCH}_{2}\right), 70.5\left(\mathrm{OCH}_{2}\right)$, $72.6\left(\mathrm{OCH}_{2}\right), 126.2(\mathrm{ArC}), 126.4(\mathrm{ArC}), 126.5(\mathrm{ArC}), 126.7(\mathrm{ArC})$, 146.5 (ArC), 146.7 (ArC), 153.6 (ArC), 155.4 (ArC) and 167.6 (CO) ppm. FABMS: $m / z: 1023.38\left(\mathrm{M}^{+}\right) . \mathrm{C}_{52} \mathrm{H}_{70} \mathrm{~N}_{4} \mathrm{O}_{9} \mathrm{~S}_{4}$ (1023.39): calcd C 61.03, H 6.89, N 5.47. Found: C 61.33, H 6.79, N 5.57.

\section{Synthesis of receptor $\mathbf{4}_{\mathrm{a}}$}

To compound 3 (150 mg, $0.147 \mathrm{mmol})$ in THF $(10 \mathrm{~mL})$, was added phenyl isocyanate $(38 \mathrm{mg}, 0.320 \mathrm{mmol})$ and the mixture was stirred for at room temperature for $24 \mathrm{~h}$ under argon. The resulting precipitate was collected by filtration, washed with hexane to give receptor $\mathbf{4}_{\mathbf{a}}$ as a white solid. Recrystallization from $\mathrm{CHCl}_{3}-\mathrm{CH}_{3} \mathrm{CN}(4: 1)$ gave receptor $\mathbf{4}_{\mathbf{a}}(154 \mathrm{mg}, 83 \%)$ as white solid. M.p. $202-205{ }^{\circ} \mathrm{C}$. IR: $\nu_{\max }(\mathrm{KBr}) / \mathrm{cm}^{-1}: 3270,2956$, 1674, 1547, 1442, 1263, 1221, 1153, 1091, 799 and $751 .{ }^{1} \mathrm{H}$ NMR $\left(300 \mathrm{MHz}, \mathrm{CDCl}_{3}-\mathrm{DMSO}, 10: 1\right): \delta=1.25(18 \mathrm{H}, \mathrm{s}, t \mathrm{Bu} \times 2), 1.39$ $(18 \mathrm{H}, \mathrm{s}, t \mathrm{Bu} \times 2), 2.97\left(4 \mathrm{H}, \mathrm{t}, J=9.1 \mathrm{~Hz}, \mathrm{OCH}_{2} \times 2\right), 3.40(4 \mathrm{H}, \mathrm{br}$, $\left.\mathrm{OCH}_{2} \times 2\right), 3.63\left(4 \mathrm{H}, \mathrm{s}, \mathrm{OCH}_{2} \times 2\right), 3.85\left(4 \mathrm{H}, \mathrm{t}, J=9.1 \mathrm{~Hz}, \mathrm{OCH}_{2}\right.$ $\times 2), 4.59\left(4 \mathrm{H}, \mathrm{s}, \mathrm{OCH}{ }_{2} \mathrm{CO} \times 2\right), 6.95(2 \mathrm{H}, \mathrm{t}, J=7.3 \mathrm{~Hz}$, phenyl $-H$ $\times 2), 7.15(4 \mathrm{H}, \mathrm{t}, J=7.6 \mathrm{~Hz}$, phenyl $H \times 4), 7.31(4 \mathrm{H}, \mathrm{d}, J=7.7$ $\mathrm{Hz}$, phenyl- $H \times 2), 7.35(4 \mathrm{H}, \mathrm{s}, \mathrm{Ar}-H \times 4), 7.48(4 \mathrm{H}, \mathrm{s}, \mathrm{Ar}-H \times 4)$, $7.57(2 \mathrm{H}, \mathrm{s}, \mathrm{N} H \times 2), 8.10(2 \mathrm{H}, \mathrm{s}, \mathrm{N} H \times 2), 8.32(2 \mathrm{H}, \mathrm{s}, \mathrm{N} H \times 2)$ ppm. ${ }^{13} \mathrm{C}$ NMR (100 MHz, $\left.\mathrm{CDCl}_{3}-\mathrm{DMSO}, 10: 1\right): \delta=29.9\left(\mathrm{CH}_{3}\right)$, $30.4\left(\mathrm{CH}_{3}\right), 33.5\left(\mathrm{C}\left(\mathrm{CH}_{3}\right)_{3}\right), 33.5\left(\mathrm{C}\left(\mathrm{CH}_{3}\right)_{3}\right), 64.9\left(\mathrm{OCH}_{2}\right), 67.5$ $\left(\mathrm{OCH}_{2}\right), 69.0\left(\mathrm{OCH}_{2}\right), 70.6\left(\mathrm{OCH}_{2}\right), 72.6\left(\mathrm{OCH}_{2}\right), 118.4(\mathrm{ArC})$, 120.4 (ArC), $121.8(\mathrm{ArC}), 125.6(\mathrm{ArC}), 126.1(\mathrm{ArC}), 126.3(\mathrm{ArC})$, 127.1 (ArC), 127.5 (ArC), 128.0 (ArC), 128.2 (ArC), 137.3 (ArC), 146.4 (ArC), 147.5 (ArC), 153.7 (ArC), 154.0 (CO), 154.6 (ArC) and 167.5 (CO) ppm. FABMS: $m / z: 1261.43\left(\mathrm{M}^{+}\right) . \mathrm{C}_{66} \mathrm{H}_{80} \mathrm{~N}_{6} \mathrm{O}_{11} \mathrm{~S}_{4}$ (1260.48): calcd C 62.83, H 6.39, N 6.66. Found: C 62.59, H 6.23, N 6.45 .

\section{Synthesis of receptor $\mathbf{4}_{b}$}

To compound 3 (150 mg, $0.147 \mathrm{mmol})$ in THF $(10 \mathrm{~mL})$, was added $p$-tolyl isocyanate $(43 \mathrm{mg}, 0.320 \mathrm{mmol})$ and the mixture was stirred for at room temperature for $24 \mathrm{~h}$ under argon. The resulting precipitate was collected by filtration, washed with
EtOH to give receptor $\mathbf{4}_{\mathbf{b}}$ as a white solid. Recrystallization from $\mathrm{CHCl}_{3}-\mathrm{CH}_{3} \mathrm{CN}(2: 1)$ gave receptor $\mathbf{4}_{\mathbf{b}}(163 \mathrm{mg}, 86 \%)$ as white solid. M.p. $205-207{ }^{\circ} \mathrm{C}$. IR: $\nu_{\max }(\mathrm{KBr}) / \mathrm{cm}^{-1}$ : 3283, 2955, 1678, 1547, 1444, 1266, 1207, 1151, 1089, 999 and 815. ${ }^{1} \mathrm{H}$ NMR ( $\left.300 \mathrm{MHz}, \mathrm{CDCl}_{3}-\mathrm{DMSO}, 10: 1\right): \delta=1.27(18 \mathrm{H}, \mathrm{s}, t \mathrm{Bu} \times 2), 1.39$ $(18 \mathrm{H}, \mathrm{s}, t \mathrm{Bu} \times 2), 2.28\left(6 \mathrm{H}, \mathrm{s}, C_{3} \times 2\right), 2.97(4 \mathrm{H}, \mathrm{t}, J=9.1 \mathrm{~Hz}$, $\left.\mathrm{OCH}_{2} \times 2\right), 3.40\left(4 \mathrm{H}, \mathrm{br}, \mathrm{OCH}_{2} \times 2\right), 3.63\left(4 \mathrm{H}, \mathrm{s}, \mathrm{OCH}_{2} \times 2\right), 3.85$ $\left(4 \mathrm{H}, \mathrm{t}, J=9.1 \mathrm{~Hz}, \mathrm{OCH}_{2} \times 2\right), 4.58\left(4 \mathrm{H}, \mathrm{s}, \mathrm{OCH}_{2} \mathrm{CO} \times 2\right), 6.96$ $(4 \mathrm{H}, \mathrm{d}, J=7.7 \mathrm{~Hz}$, phenyl- $H \times 4), 7.16(4 \mathrm{H}, \mathrm{d}, J=7.7 \mathrm{~Hz}$, phenyl$H \times 4), 7.35(4 \mathrm{H}, \mathrm{s}, \mathrm{Ar}-H \times 4), 7.48(4 \mathrm{H}, \mathrm{s}, \mathrm{Ar}-H \times 4), 7.51(2 \mathrm{H}, \mathrm{s}$, $\mathrm{N} H \times 2), 8.10(2 \mathrm{H}, \mathrm{s}, \mathrm{N} H \times 2), 8.22(2 \mathrm{H}, \mathrm{s}, \mathrm{N} H \times 2) \mathrm{ppm} .{ }^{13} \mathrm{C}$ NMR (100 MHz, $\left.\mathrm{CDCl}_{3}-\mathrm{DMSO}, 10: 1\right): \delta=20.7\left(\mathrm{CH}_{3}\right), 30.9$ $\left(\mathrm{CH}_{3}\right), 31.4\left(\mathrm{CH}_{3}\right), 34.4\left(\mathrm{C}\left(\mathrm{CH}_{3}\right)_{3}\right), 34.5\left(\mathrm{C}\left(\mathrm{CH}_{3}\right)_{3}\right), 65.9\left(\mathrm{OCH}_{2}\right)$, $68.6\left(\mathrm{OCH}_{2}\right), 70.0\left(\mathrm{OCH}_{2}\right), 71.6\left(\mathrm{OCH}_{2}\right), 73.6\left(\mathrm{OCH}_{2}\right), 119.4(\mathrm{ArC})$, 126.6 (ArC), 127.0 (ArC), 127.3 (ArC), 128.2 (ArC), 129.0 (ArC), 129.5 (ArC), 131.9 (ArC), 135.7 (ArC), 136.1 (ArC), 147.4 (ArC), 148.5 (ArC), 154.4 (ArC), 154.8 (ArC), 155.1 (CO), 155.5 (ArC) and 168.5 (CO) ppm. FABMS: $m / z: 1289.46\left(\mathrm{M}^{+}\right) . \mathrm{C}_{68} \mathrm{H}_{84} \mathrm{~N}_{6} \mathrm{O}_{11} \mathrm{~S}_{4}$ (1289.69): calcd C 63.33, H 6.56, N 6.52. Found: C 62.56, H 6.56, N 6.25 .

\section{Synthesis of receptor $\mathbf{4}_{\mathbf{c}}$}

To compound $3(150 \mathrm{mg}, 0.147 \mathrm{mmol})$ in THF $(10 \mathrm{~mL})$, was added $p$-trifluoromethylphenyl isocyanate $(59 \mathrm{mg}, 0.320 \mathrm{mmol})$ and the mixture was stirred for at room temperature for $24 \mathrm{~h}$ under argon. The resulting precipitate was collected by filtration, washed with EtOH to give receptor $\mathbf{4}_{\mathbf{c}}$ as a white solid. Recrystallization from $\mathrm{CHCl}_{3}-\mathrm{CH}_{3} \mathrm{CN}(1: 1)$ gave receptor $\mathbf{4}_{\mathbf{c}}$ (164 mg, 80\%) as white solid. M.p. $207-210{ }^{\circ} \mathrm{C}$. IR: $\nu_{\max }$ $(\mathrm{KBr}) / \mathrm{cm}^{-1}$ : 3283, 2959, 1687, 1548, 1445, 1266, 1158, 1091, 1068 and 840. ${ }^{1} \mathrm{H}$ NMR (300 MHz, $\mathrm{CDCl}_{3}$-DMSO, $\left.10: 1\right)$ : $\delta=1.27(18 \mathrm{H}, \mathrm{s}, t \mathrm{Bu} \times 2), 1.40(18 \mathrm{H}, \mathrm{s}, t \mathrm{Bu} \times 2), 2.97(4 \mathrm{H}, \mathrm{t}$, $\left.J=9.1 \mathrm{~Hz}, \mathrm{OCH}_{2} \times 2\right), 3.40\left(4 \mathrm{H}, \mathrm{br}, \mathrm{OCH}_{2} \times 2\right), 3.63(4 \mathrm{H}, \mathrm{s}$, $\left.\mathrm{OCH}_{2} \times 2\right), 3.85\left(4 \mathrm{H}, \mathrm{t}, J=9.1 \mathrm{~Hz}, \mathrm{OCH}_{2} \times 2\right), 4.61(4 \mathrm{H}, \mathrm{s}$, $\left.\mathrm{OCH}_{2} \mathrm{CO} \times 2\right), 7.36(4 \mathrm{H}, \mathrm{s}, \mathrm{Ar}-\mathrm{H} \times 4), 7.39-7.42(8 \mathrm{H}, \mathrm{m}$, phenyl- $H$ $\times 8), 7.49(4 \mathrm{H}, \mathrm{s}, \mathrm{Ar}-H \times 4), 7.56(2 \mathrm{H}, \mathrm{s}, \mathrm{N} H \times 2), 8.29(2 \mathrm{H}, \mathrm{s}, \mathrm{N} H$ $\times 2), 8.69(2 \mathrm{H}, \mathrm{s}, \mathrm{NH} \times 2) \mathrm{ppm} .{ }^{13} \mathrm{C} \mathrm{NMR}\left(100 \mathrm{MHz}, \mathrm{CDCl}_{3}-\right.$ DMSO, $10: 1): \delta=30.9\left(\mathrm{CH}_{3}\right), 31.3\left(\mathrm{CH}_{3}\right), 34.4\left(\mathrm{C}_{\left.\left(\mathrm{CH}_{3}\right)_{3}\right), 34.5}\right.$ $\left(\mathrm{C}\left(\mathrm{CH}_{3}\right)_{3}\right), 66.1\left(\mathrm{OCH}_{2}\right), 68.5\left(\mathrm{OCH}_{2}\right), 69.9\left(\mathrm{OCH}_{2}\right), 71.6\left(\mathrm{OCH}_{2}\right)$, $73.5\left(\mathrm{OCH}_{2}\right), 118.1(\mathrm{ArC}), 122.9(\mathrm{ArC}), 123.9\left(\mathrm{CF}_{3}\right), 124.2\left(\mathrm{CF}_{3}\right)$, 125.6 (ArC), $125.8(\operatorname{ArC}), 125.9(\operatorname{ArC}), 126.4(\operatorname{ArC}), 126.9(\operatorname{ArC})$, 127.0 (ArC), 128.2 (ArC), 147.4 (ArC), $148.4(\mathrm{ArC}), 154.6$ (ArC), 154.8 (CO), 155.5 (ArC) and $167.5(\mathrm{CO})$ ppm. FABMS: $m / z$ : 1397.44 $\left(\mathrm{M}^{+}\right) . \mathrm{C}_{68} \mathrm{H}_{78} \mathrm{~F}_{6} \mathrm{~N}_{6} \mathrm{O}_{11} \mathrm{~S}_{4}$ (1397.63): calcd C 58.44, H 5.63, N 6.01. Found: C 58.62, H 5.53, N 6.13.

\section{Synthesis of receptor $4_{d}$}

To compound 3 (150 mg, $0.147 \mathrm{mmol})$ in THF $(10 \mathrm{~mL})$, was added 3,5-bis(trifluoromethyl)phenyl isocyanate $(82 \mathrm{mg}$, $0.320 \mathrm{mmol}$ ) and the mixture was stirred for at room temperature for $24 \mathrm{~h}$ under argon. The resulting precipitate was collected by filtration, washed with EtOH to give receptor $\mathbf{4}_{\mathrm{d}}$ as a white solid. Recrystallization from $\mathrm{CHCl}_{3}-\mathrm{CH}_{3} \mathrm{CN}(1: 1)$ gave receptor $\mathbf{4}_{\mathbf{d}}(187 \mathrm{mg}, 83 \%)$ as white solid. M.p. $208-210{ }^{\circ} \mathrm{C}$. IR: $\nu_{\max }(\mathrm{KBr}) / \mathrm{cm}^{-1}: 3315,2963,1677,1577,1443,1215,1136,1092$, 1019 and $880 .{ }^{1} \mathrm{H}$ NMR (300 MHz, $\mathrm{CDCl}_{3}$-DMSO, $10: 1$ ): $\delta=1.32$ 
$(18 \mathrm{H}, \mathrm{s}, t \mathrm{Bu} \times 2), 1.39(18 \mathrm{H}, \mathrm{s}, t \mathrm{Bu} \times 2), 3.01(4 \mathrm{H}, \mathrm{t}, J=9.1 \mathrm{~Hz}$, $\left.\mathrm{OCH}_{2} \times 2\right), 3.40\left(4 \mathrm{H}, \mathrm{br}, \mathrm{OCH}_{2} \times 2\right), 3.64\left(4 \mathrm{H}, \mathrm{s}, \mathrm{OCH}_{2} \times 2\right), 3.89$ $\left(4 \mathrm{H}, \mathrm{t}, J=9.1 \mathrm{~Hz}, \mathrm{OCH}_{2} \times 2\right), 4.63\left(4 \mathrm{H}, \mathrm{s}, \mathrm{OCH}_{2} \mathrm{CO} \times 2\right), 7.28$ $(2 \mathrm{H}, \mathrm{s}$, phenyl- $H \times 2), 7.38(4 \mathrm{H}, \mathrm{s}, \mathrm{Ar}-H \times 4), 7.42(4 \mathrm{H}, \mathrm{s}$, phenyl$H \times 4), 7.49(4 \mathrm{H}, \mathrm{s}, \mathrm{Ar}-H \times 4), 7.82(2 \mathrm{H}, \mathrm{s}, \mathrm{N} H \times 2), 8.49(2 \mathrm{H}, \mathrm{s}$, $\mathrm{NH} \times 2), 9.05(2 \mathrm{H}, \mathrm{s}, \mathrm{NH} \times 2) \mathrm{ppm} .{ }^{13} \mathrm{C} \mathrm{NMR}\left(100 \mathrm{MHz}, \mathrm{CDCl}_{3}-\right.$ DMSO, $10: 1): \delta=30.8\left(\mathrm{CH}_{3}\right), 31.2\left(\mathrm{CH}_{3}\right), 34.3\left(\mathrm{C}\left(\mathrm{CH}_{3}\right)_{3}\right), 34.4$ $\left(\mathrm{C}\left(\mathrm{CH}_{3}\right)_{3}\right), 65.8\left(\mathrm{OCH}_{2}\right), 67.9\left(\mathrm{OCH}_{2}\right), 69.7\left(\mathrm{OCH}_{2}\right), 71.4\left(\mathrm{OCH}_{2}\right)$, $73.4\left(\mathrm{OCH}_{2}\right), 115.3$ (ArC), 117.7 (ArC), $121.6(\mathrm{ArC}), 124.3\left(\mathrm{CF}_{3}\right)$, 126.1 (ArC), 126.7 (ArC), 127.0 (ArC), 127.9 (ArC), 131.7 (ArC), 140.4 (ArC), 147.4 (ArC), 148.4 (ArC), 154.1 (ArC), 154.5 (ArC), 155.4 (CO), 155.5 (ArC) and 167.4 (CO) ppm. FABMS: $m / z$ : $1533.48\left(\mathrm{M}^{+}\right) . \mathrm{C}_{70} \mathrm{H}_{76} \mathrm{~F}_{12} \mathrm{~N}_{6} \mathrm{O}_{11} \mathrm{~S}_{4}$ (1533.63): calcd C 54.82, H 4.99, N 5.48. Found: C 54.63, H 5.05, N 5.35.

\section{Synthesis of receptor $4_{e}$}

To compound 3 (150 mg, $0.147 \mathrm{mmol})$ in THF $(10 \mathrm{~mL})$, was added $p$-nitrophenyl isocyanate $(53 \mathrm{mg}, 0.320 \mathrm{mmol})$ and the mixture was stirred for at room temperature for $24 \mathrm{~h}$ under argon. The resulting precipitate was collected by filtration, washed with EtOH to give receptor $\mathbf{4}_{\mathbf{e}}$ as a pale yellow solid. Recrystallization from $\mathrm{CHCl}_{3}-\mathrm{CH}_{3} \mathrm{CN}(3: 1)$ gave receptor $\mathbf{4}_{\mathbf{e}}(165$ $\mathrm{mg}, 83 \%)$ as pale yellow solid. M.p. $212-215{ }^{\circ} \mathrm{C}$. IR: $\nu_{\max }(\mathrm{KBr}) /$ $\mathrm{cm}^{-1}$ : 3257, 2957, 1682, 1555, 1512, 1445, 1415, 1266, 1150, 1091 and 850. ${ }^{1} \mathrm{H}$ NMR (300 MHz, $\mathrm{CDCl}_{3}$-DMSO, $10: 1$ ): $\delta=1.27$ $(18 \mathrm{H}, \mathrm{s}, t \mathrm{Bu} \times 2), 1.39(18 \mathrm{H}, \mathrm{s}, t \mathrm{Bu} \times 2), 2.97(4 \mathrm{H}, \mathrm{t}, J=9.1 \mathrm{~Hz}$, $\left.\mathrm{OCH}_{2} \times 2\right), 3.40\left(4 \mathrm{H}, \mathrm{br}, \mathrm{OCH}_{2} \times 2\right), 3.63\left(4 \mathrm{H}, \mathrm{s}, \mathrm{OCH}_{2} \times 2\right), 3.85$ $\left(4 \mathrm{H}, \mathrm{t}, J=9.1 \mathrm{~Hz}, \mathrm{OCH}_{2} \times 2\right), 4.58\left(4 \mathrm{H}, \mathrm{s}, \mathrm{OCH}_{2} \mathrm{CO} \times 2\right) 7.40(4 \mathrm{H}$, s, $\operatorname{Ar}-H \times 4), 8.57(4 \mathrm{H}, \mathrm{s}, \operatorname{Ar}-H \times 4), 7.58(4 \mathrm{H}, \mathrm{d}, J=9.3 \mathrm{~Hz}$, phenyl- $H \times 4), 7.66(2 \mathrm{H}, \mathrm{s}, \mathrm{N} H \times 2), 8.06(4 \mathrm{H}, \mathrm{d}, J=9.3 \mathrm{~Hz}$, phenyl- $H \times 4), 8.40(2 \mathrm{H}, \mathrm{s}, \mathrm{N} H \times 2), 9.08(2 \mathrm{H}, \mathrm{s}, \mathrm{N} H \times 2) \mathrm{ppm}$. ${ }^{13} \mathrm{C}$ NMR (100 MHz, $\left.\mathrm{CDCl}_{3}-\mathrm{DMSO}, 10: 1\right): \delta=30.9\left(\mathrm{CH}_{3}\right), 31.3$ $\left(\mathrm{CH}_{3}\right), 34.4\left(\mathrm{C}\left(\mathrm{CH}_{3}\right)_{3}\right), 34.5\left(\mathrm{C}\left(\mathrm{CH}_{3}\right)_{3}\right), 66.2\left(\mathrm{OCH}_{2}\right), 69.0\left(\mathrm{OCH}_{2}\right)$, $69.9\left(\mathrm{OCH}_{2}\right), 71.7\left(\mathrm{OCH}_{2}\right), 73.6\left(\mathrm{OCH}_{2}\right), 118.1(\mathrm{ArC}), 124.9(\mathrm{ArC})$, 126.2 (ArC), 127.1 (ArC), 127.7 (ArC), 128.0 (ArC), 128.4 (ArC), 142.6 (ArC), 144.5 (ArC), 147.5 (ArC), 147.3 (ArC), 147.9 (ArC), 148.2 (ArC), 154.0 (ArC), 154.2 (CO), 155.7 (ArC) and 168.5 (CO) ppm. FABMS: $m / z: 1351.57\left(\mathrm{M}^{+}\right) \cdot \mathrm{C}_{66} \mathrm{H}_{78} \mathrm{~N}_{8} \mathrm{O}_{15} \mathrm{~S}_{4}$ (1351.63): calcd C 58.65, H 5.82, N 8.29. Found: C 58.81, H 5.75, N 8.12.

\section{Determination of the association constants}

The association constants were determined by using ${ }^{1} \mathrm{H}$ NMR spectroscopic titration experiments in a constant concentration of host receptor $\left(4.0 \times 10^{-3} \mathrm{M}\right)$ and varying the guest concentration $\left(0-8.0 \times 10^{-3} \mathrm{M}\right)$. The ${ }^{1} \mathrm{H}$ NMR chemical shift of the urea protons $(\mathrm{NH})$ signal was used as a probe. The association constant $\left(K_{\mathrm{a}}\right)$ for the complexes of receptor $\mathbf{4}_{\mathbf{a}-\mathbf{e}}$ were calculated by nonlinear curve-fitting analysis of the observed chemical shifts of the $\mathrm{NH}$ protons according to the literature procedure. ${ }^{\mathbf{1 4}}$

\section{${ }^{1} \mathrm{H}$ NMR titration experiments}

A solution of $\mathrm{Bu}_{4} \mathrm{NX}\left(\mathrm{X}=\mathrm{F}, \mathrm{Cl}, \mathrm{Br}, \mathrm{I}, \mathrm{AcO}, \mathrm{PhCOO}, \mathrm{H}_{2} \mathrm{PO}_{4}\right)$ in

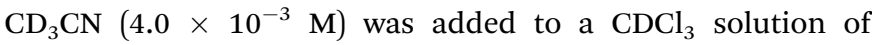
receptor $\mathbf{4}_{\mathbf{a}-\mathbf{e}}$ in the absence or presence of $\mathrm{KSO}_{3} \mathrm{CF}_{3}$ in an NMR tube. ${ }^{1} \mathrm{H}$ NMR spectra were recorded after addition of the reactants and the temperature of the NMR probe was kept constant at $27{ }^{\circ} \mathrm{C}$. The ${ }^{1} \mathrm{H}$ NMR spectroscopic data of representative complexes are given below:

Receptor $\mathbf{4}_{\mathbf{a}} \supset \mathbf{C l}^{-} .{ }^{1} \mathrm{H}$ NMR $\left(300 \mathrm{MHz}, \mathrm{CHCl}_{3}-\mathrm{DMSO}-\right.$ $\left.\mathrm{CH}_{3} \mathrm{CN}, 10: 1: 1, \mathrm{v} / \mathrm{v}\right): \delta=2.97\left(4 \mathrm{H}, \mathrm{br}, \mathrm{OCH}_{2} \times 2\right), 3.40(4 \mathrm{H}, \mathrm{br}$, $\left.\mathrm{OCH}_{2} \times 2\right), 3.63\left(4 \mathrm{H}, \mathrm{br}, \mathrm{OCH}_{2} \times 2\right), 3.85\left(4 \mathrm{H}, \mathrm{br}, \mathrm{OCH}_{2} \times 2\right)$, $4.59\left(4 \mathrm{H}, \mathrm{s}, \mathrm{OCH}_{2} \mathrm{O} \times 2\right), 7.89\left(2 \mathrm{H}, \mathrm{br}, \mathrm{NH} \mathrm{c}_{\mathrm{c}} \times 2\right), 8.10(2 \mathrm{H}, \mathrm{br}$, $\left.\mathrm{N} H_{\mathrm{b}} \times 2\right)$ and $8.95\left(2 \mathrm{H}, \mathrm{br}, \mathrm{NH}_{\mathrm{a}} \times 2\right) \mathrm{ppm}$.

Receptor $\mathbf{4}_{\mathbf{b}} \supset \mathbf{C l}^{-} \cdot{ }^{1} \mathrm{H}$ NMR (300 $\mathrm{MHz}, \mathrm{CHCl}_{3}-\mathrm{DMSO}-$ $\left.\mathrm{CH}_{3} \mathrm{CN}, 10: 1: 1, \mathrm{v} / \mathrm{v}\right): \delta=2.97\left(4 \mathrm{H}, \mathrm{br}, \mathrm{OCH}_{2} \times 2\right), 3.40(4 \mathrm{H}, \mathrm{br}$, $\left.\mathrm{OCH}_{2} \times 2\right), 3.63\left(4 \mathrm{H}, \mathrm{br}, \mathrm{OCH}_{2} \times 2\right), 3.85\left(4 \mathrm{H}, \mathrm{br}, \mathrm{OCH}_{2} \times 2\right)$, $4.68\left(4 \mathrm{H}, \mathrm{s}, \mathrm{OCH}_{2} \mathrm{O} \times 2\right), 7.80\left(2 \mathrm{H}, \mathrm{br}, \mathrm{NH} \mathrm{c}_{\mathrm{c}} \times 2\right), 8.09(2 \mathrm{H}, \mathrm{br}$, $\left.\mathrm{N} H_{\mathrm{b}} \times 2\right)$ and $8.63\left(2 \mathrm{H}, \mathrm{br}, \mathrm{NH}_{\mathrm{a}} \times 2\right) \mathrm{ppm}$.

Receptor $\mathbf{4}_{\mathbf{c}} \supset \mathrm{Cl}^{-} \cdot{ }^{1} \mathrm{H}$ NMR (300 $\mathrm{MHz}, \mathrm{CHCl}_{3}$-DMSO$\left.\mathrm{CH}_{3} \mathrm{CN}, 10: 1: 1, \mathrm{v} / \mathrm{v}\right): \delta=2.97\left(4 \mathrm{H}, \mathrm{br}, \mathrm{OCH}_{2} \times 2\right), 3.40(4 \mathrm{H}, \mathrm{br}$, $\left.\mathrm{OCH}_{2} \times 2\right), 3.63\left(4 \mathrm{H}, \mathrm{br}, \mathrm{OCH}_{2} \times 2\right), 3.85\left(4 \mathrm{H}, \mathrm{br}, \mathrm{OCH}_{2} \times 2\right)$, $4.68\left(4 \mathrm{H}, \mathrm{s}, \mathrm{OCH}_{2} \mathrm{O} \times 2\right), 8.01\left(2 \mathrm{H}, \mathrm{br}, \mathrm{NH}_{\mathrm{c}} \times 2\right), 8.20(2 \mathrm{H}, \mathrm{br}$, $\left.\mathrm{N} H_{\mathrm{b}} \times 2\right)$ and $9.58\left(2 \mathrm{H}, \mathrm{br}, \mathrm{NH}_{\mathrm{a}} \times 2\right) \mathrm{ppm}$.

Receptor $\mathbf{4}_{\mathbf{d}} \supset \mathbf{C l}^{-} .{ }^{1} \mathrm{H}$ NMR $\left(300 \mathrm{MHz}, \mathrm{CHCl}_{3}-\mathrm{DMSO}-\right.$ $\left.\mathrm{CH}_{3} \mathrm{CN}, 10: 1: 1, \mathrm{v} / \mathrm{v}\right): \delta=3.01\left(4 \mathrm{H}, \mathrm{br}, \mathrm{OCH}_{2} \times 2\right), 3.40(4 \mathrm{H}, \mathrm{br}$, $\left.\mathrm{OCH}_{2} \times 2\right), 3.64\left(4 \mathrm{H}, \mathrm{br}, \mathrm{OCH}_{2} \times 2\right), 3.89\left(4 \mathrm{H}, \mathrm{br}, \mathrm{OCH}_{2} \times 2\right)$, $4.63\left(4 \mathrm{H}, \mathrm{s}, \mathrm{OCH}_{2} \mathrm{O} \times 2\right), 7.94\left(2 \mathrm{H}, \mathrm{br}, \mathrm{N} H_{\mathrm{c}} \times 2\right), 8.33(2 \mathrm{H}, \mathrm{br}$, $\left.\mathrm{N} H_{\mathrm{b}} \times 2\right)$ and $9.70\left(2 \mathrm{H}, \mathrm{br}, \mathrm{NH}_{\mathrm{a}} \times 2\right) \mathrm{ppm}$.

Receptor $\mathbf{4}_{\mathbf{e}} \supset \mathbf{C l}^{-} \cdot{ }^{1} \mathrm{H}$ NMR $\left(300 \mathrm{MHz}, \mathrm{CHCl}_{3}-\mathrm{DMSO}-\right.$ $\left.\mathrm{CH}_{3} \mathrm{CN}, 10: 1: 1, \mathrm{v} / \mathrm{v}\right): \delta=2.97\left(4 \mathrm{H}, \mathrm{br}, \mathrm{OCH}_{2} \times 2\right), 3.40(4 \mathrm{H}, \mathrm{br}$, $\left.\mathrm{OCH}_{2} \times 2\right), 3.63\left(4 \mathrm{H}, \mathrm{br}, \mathrm{OCH}_{2} \times 2\right), 3.85\left(4 \mathrm{H}, \mathrm{br}, \mathrm{OCH}_{2} \times 2\right)$, $4.60\left(4 \mathrm{H}, \mathrm{s}, \mathrm{OCH}_{2} \mathrm{O} \times 2\right), 8.10\left(2 \mathrm{H}, \mathrm{br}, \mathrm{N} H_{\mathrm{c}} \times 2\right), 8.18(2 \mathrm{H}, \mathrm{br}$, $\left.\mathrm{N} H_{\mathrm{b}} \times 2\right)$ and $10.8\left(2 \mathrm{H}, \mathrm{br}, \mathrm{NH}_{\mathrm{a}} \times 2\right) \mathrm{ppm}$.

Receptor $\mathbf{4}_{\mathbf{e}} \supset \mathrm{K}^{+} .{ }^{1} \mathrm{H}$ NMR $\left(300 \mathrm{MHz}, \mathrm{CHCl}_{3}-\mathrm{DMSO}-\mathrm{CH}_{3} \mathrm{CN}\right.$, $10: 1: 1, \mathrm{v} / \mathrm{v}): \delta=3.11\left(4 \mathrm{H}, \mathrm{br}, \mathrm{OCH}_{2} \times 2\right), 3.36-3.58(4 \mathrm{H}, \mathrm{m}$, $\left.\mathrm{OCH}_{2} \times 2\right), 3.64-3.90\left(4 \mathrm{H}, \mathrm{m}, \mathrm{OCH}_{2} \times 2\right), 4.08\left(4 \mathrm{H}, \mathrm{br}, \mathrm{OCH}_{2} \times\right.$ 2), 4.30-4.61 (4H, m, $\left.\mathrm{OCH}_{2} \mathrm{O} \times 2\right), 8.10\left(2 \mathrm{H}, \mathrm{s}, \mathrm{N} H_{\mathrm{c}} \times 2\right), 8.95$ $\left(2 \mathrm{H}\right.$, broad s, $\left.\mathrm{NH}_{\mathrm{b}} \times 2\right)$ and $9.09\left(2 \mathrm{H}\right.$, broad s, $\left.\mathrm{NH}_{\mathrm{a}} \times 2\right) \mathrm{ppm}$.

$\mathbf{C l}^{-} \subset\left[\right.$ receptor $\left.\mathbf{4}_{\mathbf{e}} \supset \mathbf{K}^{+}\right]$. ${ }^{1} \mathrm{H}$ NMR $\left(300 \mathrm{MHz}, \mathrm{CHCl}_{3}-\mathrm{DMSO}-\right.$ $\left.\mathrm{CH}_{3} \mathrm{CN}, 10: 1: 1, \mathrm{v} / \mathrm{v}\right): \delta=2.97\left(4 \mathrm{H}, \mathrm{br}, \mathrm{OCH}_{2} \times 2\right), 3.40(4 \mathrm{H}, \mathrm{br}$, $\left.\mathrm{OCH}_{2} \times 2\right), 3.63\left(4 \mathrm{H}, \mathrm{br}, \mathrm{OCH}_{2} \times 2\right), 3.85\left(4 \mathrm{H}, \mathrm{br}, \mathrm{OCH}_{2} \times 2\right)$, $4.60\left(4 \mathrm{H}, \mathrm{s}, \mathrm{OCH}_{2} \mathrm{O} \times 2\right), 8.14\left(2 \mathrm{H}, \mathrm{br}, \mathrm{NH} \mathrm{c}_{\mathrm{c}} \times 2\right), 8.58(2 \mathrm{H}, \mathrm{br}$, $\left.\mathrm{N} H_{\mathrm{b}} \times 2\right)$ and $10.2\left(2 \mathrm{H}, \mathrm{br}, \mathrm{NH}_{\mathrm{a}} \times 2\right) \mathrm{ppm}$.

Receptor $\mathbf{4}_{\mathbf{e}} \supset \mathbf{B r}^{-} \cdot{ }^{1} \mathrm{H}$ NMR (300 $\mathrm{MHz}, \mathrm{CHCl}_{3}$-DMSO$\left.\mathrm{CH}_{3} \mathrm{CN}, 10: 1: 1, \mathrm{v} / \mathrm{v}\right): \delta=2.97\left(4 \mathrm{H}, \mathrm{br}, \mathrm{OCH}_{2} \times 2\right), 3.40(4 \mathrm{H}, \mathrm{br}$, $\left.\mathrm{OCH}_{2} \times 2\right), 3.63\left(4 \mathrm{H}, \mathrm{br}, \mathrm{OCH}_{2} \times 2\right), 3.85\left(4 \mathrm{H}, \mathrm{br}, \mathrm{OCH}_{2} \times 2\right)$, $4.60\left(4 \mathrm{H}, \mathrm{s}, \mathrm{OCH}_{2} \mathrm{O} \times 2\right), 7.52\left(2 \mathrm{H}, \mathrm{br}, \mathrm{NH}_{\mathrm{c}} \times 2\right), 8.25(2 \mathrm{H}, \mathrm{br}$, $\left.\mathrm{NH}_{\mathrm{b}} \times 2\right)$ and $9.27\left(2 \mathrm{H}, \mathrm{br}, \mathrm{NH}_{\mathrm{a}} \times 2\right)$.

$\mathbf{B r}^{-} \subset\left[\right.$ receptor $\mathbf{4}_{\mathbf{e}} \supset \mathbf{K}^{+}$]. ${ }^{1} \mathrm{H}$ NMR $\left(300 \mathrm{MHz}, \mathrm{CHCl}_{3}-\mathrm{DMSO}-\right.$ $\left.\mathrm{CH}_{3} \mathrm{CN}, 10: 1: 1, \mathrm{v} / \mathrm{v}\right): \delta=3.11\left(4 \mathrm{H}, \mathrm{br}, \mathrm{OCH}_{2} \times 2\right), 3.36-3.58$ $\left(4 \mathrm{H}, \mathrm{m}, \mathrm{OCH}_{2} \times 2\right), 3.64-3.90\left(4 \mathrm{H}, \mathrm{m}, \mathrm{OCH}_{2} \times 2\right), 4.08(4 \mathrm{H}, \mathrm{br}$, $\left.\mathrm{OCH}_{2} \times 2\right), 4.30-4.61\left(4 \mathrm{H}, \mathrm{m}, \mathrm{OCH}_{2} \mathrm{O} \times 2\right), 7.81\left(2 \mathrm{H}, \mathrm{br}, \mathrm{N} H_{\mathrm{c}} \times\right.$ 2), $8.10\left(2 \mathrm{H}, \mathrm{br}, \mathrm{NH}_{\mathrm{b}} \times 2\right)$ and $9.51\left(2 \mathrm{H}, \mathrm{br}, \mathrm{N} H_{\mathrm{a}} \times 2\right)$.

\section{Crystallographic analysis of receptors $4_{b}$ and $4_{e}$}

Crystal data for $4_{\mathbf{b}} \cdot \mathrm{C}_{68} \mathrm{H}_{84} \mathrm{~N}_{6} \mathrm{O}_{11} \mathrm{~S}_{4} \cdot 1 / 2\left(\mathrm{H}_{2} \mathrm{O}\right) \cdot 1 \frac{1}{2}\left(\mathrm{CHCl}_{3}\right), M_{\mathrm{r}}=$ 1477.71. Monoclinic, $P 2_{1} / n ; a=18.8935$ (13), $b=23.9302$ (16), $c=33.589$ (2) $\AA$; $\beta=91.5063(12)^{\circ} ; V=15181.2(17) \AA^{3} ; Z=8$; $D_{x}=1.293 \mathrm{Mg} \mathrm{m}^{-3} ; F(000)=6224 ; T=210(2) \mathrm{K} ; \mu\left(\mathrm{Mo}_{\alpha}\right)=$ $0.34 \mathrm{~mm}^{-1} ; \lambda=0.71073 \AA$ A, crystal size $0.71 \times 0.54 \times 0.32 \mathrm{~mm}^{3}$. Crystals were colorless blocks. Diffraction data were measured on a Bruker APEX 2 CCD diffractometer equipped with graphite 
monochromated $\mathrm{Mo}_{\mathrm{K} \alpha}$ radiation by thin-slice $\omega$-scans. ${ }^{15} 134900$ measured reflections, 31218 independent reflections $\left(R_{\text {int }}=0.049\right)$ to $\theta_{\max }=26.5^{\circ} ; 19539$ reflections with $I>2 \sigma(I)$. The structure was determined by direct methods using the SHELXS program and refined by the full-matrix least-squares method, on $F^{2}$, in SHELXL-2013/14. ${ }^{16,17}$ The non-hydrogen atoms were refined with anisotropic thermal parameters. Hydrogen atoms on $\mathrm{C}$ were included in idealized positions and their $U_{\text {iso }}$ values were set to ride on the $U_{\text {eq }}$ values of the parent atoms. $\mathrm{H}$ atoms on $\mathrm{N}$ were freely refined. At the conclusion of the refinement, $\mathrm{w} R_{2}=0.173$ (all data) and $R_{1}=0.056$ (observed data), 1903 parameters, $\Delta\rangle_{\max }=0.56 \mathrm{e}^{-3} ; 465$ restraints, $\left.\Delta\right\rangle_{\min }$ $=-0.43 \mathrm{e \AA}^{-3}$. The platon squeeze procedure was used to model two of the three unique $\mathrm{CHCl}_{3}$ molecules due to severe disorder. ${ }^{18}$ Two-fold disorder was modelled in some $t$ Bu groups, in parts of one of the crown ether chains and the other $\mathrm{CHCl}_{3}$ molecule. $\mathrm{H}$ atoms on water molecule $\mathrm{O}(23)$ could not be located in difference maps, so were not included in the model. $\dagger$

Crystal data for $4_{\mathrm{e}} \cdot \mathrm{C}_{66} \mathrm{H}_{78} \mathrm{~N}_{8} \mathrm{O}_{15} \mathrm{~S}_{4} \cdot 1 / 2\left(\mathrm{CHCl}_{3}\right) \cdot 3(\mathrm{MeCN})$, $M_{\mathrm{r}}=1534.44$. Monoclinic, $P 2_{1} / c ; a=17.7980$ (10), $b=26.7870$ (16), $c=32.552$ (2) $\AA$; $\beta=96.384(4)^{\circ} ; V=15423.1$ (16) $\AA^{3} ; Z=8$; $D_{x}=1.322 \mathrm{Mg} \mathrm{m}^{-3} ; F(000)=6472 ; T=100$ (2) K; $\mu$ (Mo$\mathrm{K} \alpha)=0.31 \mathrm{~mm}^{-1} ; \lambda=0.7749 \AA$, crystal size $0.25 \times 0.25 \times 0.02$ $\mathrm{mm}^{3}$. Crystals were colorless plates. Diffraction data were measured on a Bruker APEX 2 CCD diffractometer at station 11.3.1 of the ALS using synchrotron radiation by thin-slice $\omega$ scans. ${ }^{15} 155885$ measured reflections, 50956 independent reflections $\left(R_{\text {int }}=0.052\right)$ to $\theta_{\max }=34.8^{\circ} ; 35702$ reflections with $I$ $>2 \sigma(I)$. Structure solution with SHELXT and refinement as above. ${ }^{16,17}$ Hydrogen atoms on $\mathrm{C}$ and some $\mathrm{N}$ atoms were included in idealized positions and their $U_{\text {iso }}$ values were set to ride on the $U_{\text {eq }}$ values of the parent atoms. $\mathrm{H}$ atoms on the remaining $\mathrm{N}$ atoms were freely refined. At the conclusion of the refinement, $\mathrm{w} R_{2}=0.294$ (all data) and $R_{1}=0.086$ (observed data), 2055 parameters, $\Delta\rangle_{\max }=2.44 \mathrm{e}^{-3} ; 656$ restraints, $\left.\Delta\right\rangle_{\min }$ $=-1.86 \mathrm{e \AA}^{-3}$. The platon squeeze procedure was used to model four of the six unique MeCN molecules due to severe disorder. ${ }^{18}$ Two-fold disorder was modelled in some $t \mathrm{Bu}$ groups and in parts of one the crown ether chains and one $\mathrm{HN}-p-\mathrm{C}_{6} \mathrm{H}_{4} \mathrm{NO}_{2}$ group. $\dagger$

\section{Acknowledgements}

This work was performed under the Cooperative Research Program of "Network Joint Research Center for Materials and Devices (Institute for Materials Chemistry and Engineering, Kyushu University)". We would like to thank the OTEC at Saga University and the International Cooperation Projects of Guizhou Province (no. 20137005) for financial support. CR thanks the EPSRC for a travel grant. The Advanced Light Source is supported by the Director, Office of Science, Office of Basic Energy Sciences, of the U.S. Department of Energy under Contract no. DE-AC02-05CH11231.

\section{Notes and references}

1 (a) C. D. Gutsche, Calixarenes, An Introduction, Royal Society of Chemistry, Cambridge, UK, 2008; (b) A. Ikeda and
S. Shinkai, Chem. Rev., 1997, 97, 1713-1734; (c) D. Coquière, S. Le Gac, U. Darbost, O. Sénèque, I. Jabin and O. Reinaud, Org. Biomol. Chem., 2009, 7, 2485-2500; (d) K. Cottet, P. M. Marcos and P. J. Cragg, Beilstein J. Org. Chem., 2012, 8, 201-226; (e) L. Mutihac, J. H. Lee, J. S. Kim and J. Vicens, Chem. Soc. Rev., 2011, 40, 2777-2796; (f) L. Baldini, A. Casnati, F. Sansone and R. Ungaro, Chem. Soc. Rev., 2007, 36, 254-266; (g) J. S. Kim and D. T. Quang, Chem. Rev., 2007, 107, 3780-3799; (h) R. Joseph and C. P. Rao, Chem. Rev., 2011, 111, 4658-4702; (i) C. Capici, Y. Cohen, A. D'Urso, G. Gattuso, A. Notti, A. Pappalardo, S. Pappalardo, M. F. Parisi, R. Purrello, S. Slovak and V. Villari, Angew. Chem., Int. Ed., 2011, 50, 12162-12167; (j) C. Talotta, C. Gaeta, Z. Qi, C. A. Schalley and P. Neri, Angew. Chem., Int. Ed., 2013, 52, 7437-7441; (k) M.-X. Wang, Acc. Chem. Res., 2012, 45, 182-195.

2 H. Kumagi, M. Hasegawa, S. Miyanari, Y. Sugawa, Y. Sato, T. Hori, S. Ueda, H. Kamiyama and S. Miyano, Tetrahedron Lett., 1997, 38, 3971-3972.

3 (a) P. Lhoták, Eur. J. Org. Chem., 2004, 1675-1692; (b) N. Morohashi, F. Narumi, N. Iki, T. Hattori and S. Miyano, Chem. Rev., 2006, 106, 5291-5316.

4 (a) P. D. Beer and P. A. Gale, Angew. Chem., Int. Ed., 2001, 40, 486-516; (b) T. Nabeshima, T. Saiki and S. Kumitomo, Org. Lett., 2002, 4, 3207-3209; (c) T. Nabeshima, Y. Yoshihira, T. Saiki, S. Akine and E. Horn, J. Am. Chem. Soc., 2003, 125, 28-29; (d) A. Y. Zhukov, T. A. Fink, I. I. Stoikov and I. S. Antipin, Russ. Chem. Bull., 2009, 58, 1007-1014; (e) K. Mohr, J. Schmitz, R. Schrage, C. Trnkle and U. Holzgrabe, Angew. Chem., Int. Ed., 2013, 52, 508-516; (f) R. Nussinov and C.-J. Tsai, Cell, 2013, 153, 293-305.

5 (a) J.-Y. Kwon, Y.-J. Jang, S.-K. Kim, K.-H. Lee, J.-S. Kim and J. Yoon, J. Org. Chem., 2004, 69, 5155-5157; (b) D. Amilan Jose, D. K. Kumar, B. Ganguly and A. Das, Org. Lett., 2004, 6, 3445-3448; (c) J.-Y. Lee, E.-J. Cho, S. Mukamel and K.-C. Nam, J. Org. Chem., 2004, 69, 943-950; (d) D. EstebanGómez, L. Fabbrizzi and M. Licchelli, J. Org. Chem., 2005, 70, 5717-5720; (e) V. Thiagarajan, P. Ramamurthy, D. Thirumalai and V. T. Ramakrishnan, Org. Lett., 2005, 7, 657-660; (f) H. Lu, W. Xu, D. Zhang, C. Chen and D. Zhu, Org. Lett., 2005, 7, 4629-4632; $(g)$ F. M. Pfeffer, T. Gunnlaugsson, P. Jensen and P. E. Kruger, Org. Lett., 2005, 7, 5357-5360; (h) L. Fang, W.-H. Chan, Y.-B. He, D. W.-J. Kwong and A. W.-M. Lee, J. Org. Chem., 2005, 70, 7640-7646; ( $i$ ) T. Gunnlaugsson, P. E. Kruger, P. Jensen, J. Tierney, H. D. Paduka Ali and G. M. Hussey, J. Org. Chem., 2005, 70, 10875-10878; (j) A. Dahan, T. Ashkenazi, V. Kuznetsov, S. Makievski, E. Drug, L. Fadeev, M. Bramson, S. Schokoroy, E. Rozenshine-Kemelmakher and M. Gozin, J. Org. Chem., 2007, 72, 2289-2296; (k) S. Saha, A. Ghosh, P. Mahato, S. Mishra, S. K. Mishra, E. Suresh, S. Das and A. Das, Org. Lett., 2010, 12, 3406-3409. 6 J. L. Sessler, P. A. Gale and W. S. Cho, Anion Receptor Chemistry, Royal Society of Chemistry, Cambridge, U.K., 2006. 
7 (a) J. F. Zhang, Y. Zhou, J. Yoon and J. S. Kim, Chem. Soc. Rev., 2011, 40, 3416-3429; (b) C. Lodeiro, J. L. Capelo, J. C. Mejuto, E. Oliveira, H. M. Santos, B. Pedras and C. Nuñez, Chem. Soc. Rev., 2010, 39, 2948-2976; (c) L. E. Santos-Figueroa, M. E. Moragues, E. Climent, A. Agostini, R. Martínez-Máñez and F. Sancenón, Chem. Soc. Rev., 2013, 42, 3489-3613.

8 (a) R. M. F. Batista, E. Oliveira, S. P. G. Costa, C. Lodeiro and M. M. M. Raposo, Org. Lett., 2007, 9, 3201-3204; (b) F. Zapata, A. Caballero, A. Espinosa, A. Tárraga and P. Molina, Org. Lett., 2008, 10, 41-44; (c) R. D. Rasberry, M. D. Smith and K. D. Shimizu, Org. Lett., 2008, 10, 2889-2892; (d) C. PérezCasas and A. K. Yatsimirsky, J. Org. Chem., 2008, 73, 22752284; (e) J. P. Clare, A. Statnikov, V. Lynch, A. L. Sargent and J. W. Sibert, J. Org. Chem., 2009, 74, 6637-6646; (f) Q.-S. Lu, L. Dong, J. Zhang, J. Li, L. Jiang, Y. Huang, S. Qin, C.-W. Hu and X.-Q. Yu, Org. Lett., 2009, 11, 669-672; $(g)$ S. Goswami, D. Sen and N. K. Das, Org. Lett., 2010, 12, 856859; (h) A. Aldrey, C. Nứñez, V. García, R. Bastida, C. Lodeiro and A. Macías, Tetrahedron, 2010, 66, 92239230; ( $i$ ) P. Dydio, T. Zieliński and J. Jurczak, Org. Lett., 2010, 12, 1076-1078; (j) V. K. Bhardwaj, S. Sharma, N. Singh, M. S. Hundal and G. Hundal, Supramol. Chem., 2011, 23, 790-800; ( $k$ ) G.-W. Lee, N.-K. Kim and K.-S. Jeong, Org. Lett., 2011, 13, 3024-3027; (l) H. M. Chawla, S. N. Sahu, R. Shrivastava and S. Kumar, Tetrahedron Lett., 2012, 53, 2244-2247; (m) S. Goswami, A. Manna, S. Paul, K. Aich, A. K. Das and S. Chakraborty, Tetrahedron Lett., 2013, 54, 1785-1789; (n) K. Pandurangan, J. A. Kitchen and T. Gunnlaugsson, Tetrahedron Lett., 2013, 54, 2770-2775; (o) S. Areti, J. K. Khedkar, R. Chilukula and C. P. Rao, Tetrahedron Lett., 2013, 54, 5629-5634; (p) C. Jin, M. Zhang, C. Deng, Y. Guan, J. Gong, D. Zhu, Y. Pan, J. Jiang and L. Wang, Tetrahedron Lett., 2013, 54, 796-801.

9 (a) K. Lang, P. Cuřínová, M. Dudič, P. Prošcová, I. Stibor, V. Št'astný and P. Lhoták, Tetrahedron Lett., 2005, 46, 44694472; (b) P. Lhoták, J. Svoboda and I. Stibor, Tetrahedron Lett., 2006, 62, 1253-1257; (c) J. Kroupa, I. Stibor, M. Pojarová, M. Tkadlecová and P. Lhoták, Tetrahedron, 2008, 64, 10075-10079; (d) O. Kundrat, H. Dvorakova, I. Cisarova, M. Pojarova and P. Lhoták, Org. Lett., 2009, 11, 4188-4191; (e) O. Kundrat, I. Cisarova, S. Böhm, M. Pojarova and P. Lhoták, J. Org. Chem., 2009, 74, 45924596; ( $f$ ) O. Kundrat, H. Dvorakova, V. Eigner and P. Lhoták, J. Org. Chem., 2010, 75, 407-411; (g) O. Kundrat, J. Kroupa, S. Böhm, J. Budka, V. Eigner and P. Lhoták, J. Org. Chem., 2010, 75, 8372-8375; (h) O. Kundrát, V. Eigner, P. Cuř́nová, J. Kroupa and P. Lhoták, Tetrahedron, 2011, 67, 8367-8372; ( $i$ ) O. Kundrat, V. Eigner, H. Dvorakova and P. Lhoták, Org. Lett., 2011, 13, 4032-4035; (j) P. Slavik, M. Dudic, K. Flidrova, J. Sykora, I. Cisarova, M. Pojarova and P. Lhoták, Org. Lett., 2012, 14, 3628-3631; (k) O. Kundrat, H. Dvorakova, S. Böhm, V. Eigner and P. Lhoták, J. Org. Chem., 2012, 77, 2272-2278.
10 (a) V. Bhalla, M. Kumar, H. Katagiri, T. Hattori and S. Miyano, Tetrahedron Lett., 2005, 46, 121-124; (b) V. Bhalla, J. N. Babu, M. Kumar, T. Hattori and S. Miyano, Tetrahedron Lett., 2007, 48, 1581-1585; (c) V. Bhalla, R. Kumar, M. Kumar and A. Dhir, Tetrahedron, 2007, 63, 11153-11159; (d) A. Dhir, V. Bhalla and M. Kumar, Org. Lett., 2008, 10, 4891-4894; (e) R. Kumar, V. Bhalla and M. Kumar, Tetrahedron, 2008, 64, 8095-8101; $(f)$ R. K. Mahajan, R. Kaur, V. Bhalla, M. Kumar, T. Hattori and S. Miyano, Sens. Actuators, B, 2008, 130, 290-294; $(g)$ J. N. Babu, V. Bhalla, M. Kumar, R. K. Mahajan and R. K. Puri, Tetrahedron Lett., 2008, 49, 2772-2775; (h) M. Kumar, A. Dhir and V. Bhalla, Org. Lett., 2009, 11, 2567-2570; ( $i$ ) M. Kumar, R. Kumar and V. Bhalla, Tetrahedron, 2009, 65, 4340-4344; (j) M. Kumar, A. Dhir and V. Bhalla, Org. Lett., 2009, 11, 2567-2570; (k) M. Kumar, R. Kumar and V. Bhalla, Tetrahedron Lett., 2010, 51, 5559-5562; (l) M. Kumar, R. Kumar and V. Bhalla, Org. Lett., 2011, 13, 366-369; $(m)$ M. Kumar, R. Kumar and V. Bhalla, Org. Biomol. Chem., 2011, 9, 8237-8245; (n) M. Kumar, R. Kumar and V. Bhalla, Org. Lett., 2011, 13, 366-369; (o) M. Kumar, R. Kumar and V. Bhalla, Tetrahedron Lett., 2013, 54, 1524-1527.

11 (a) C. Perez-Casas and T. Yamato, J. Inclusion Phenom. Macrocyclic Chem., 2005, 53, 1-8; (b) T. Yamato, C. PerezCasas, H. Yamamoto, M. R. J. Elsegood, S. H. Dale and C. Redshaw, J. Inclusion Phenom. Macrocyclic Chem., 2006, 54, 261-269; (c) C. Perez-Casas, S. Rahman, N. Begum, Z. Xi and T. Yamato, J. Inclusion Phenom. Macrocyclic Chem., 2008, 60, 173-185; (d) X.-L. Ni, X. Zeng, C. Redshaw and T. Yamato, J. Org. Chem., 2011, 76, 3358-3370; (e) X.-L. Ni, X. Zeng, C. Redshaw and T. Yamato, Tetrahedron, 2011, 67, 3248-3253; (f) X.-L. Ni, J. Tahara, S. Rahman, X. Zeng, D. L. Hughes, C. Redshaw and T. Yamato, Chem.Asian J., 2012, 7, 519-527; (g) X.-L. Ni, H. Cong, A. Yoshizawa, S. Rahman, H. Tomiyasu, U. Rayhan, X. Zeng and T. Yamato, J. Mol. Struct., 2013, 1046, 110-115. 12 F. W. B. van Leewen, H. Beijleveld, H. Kooijman, A. L. Spek, W. Verboom and D. N. Reinhoudt, J. Org. Chem., 2004, 69, 3928-3936.

13 N. Iki, N. Morohashi, F. Narumi, T. Fujimoto, T. Suzuki and S. Miyano, Tetrahedron Lett., 1999, 40, 7337-7341.

14 H. A. Benesi and J. H. Hildebrand, J. Am. Chem. Soc., 1949, 71, 2703-2707.

15 APEX 2 and SAINT, Software for CCD diffractometers, Bruker AXS Inc., Madison, USA, 2011.

16 G. M. Sheldrick, Acta Crystallogr., Sect. A: Found. Crystallogr., 2008, 64, 112-122.

17 G. M. Sheldrick, Acta Crystallogr., Sect. A: Found. Adv., 2015, 71, 3-8.

18 A. L. Spek, Acta Crystallogr., Sect. A: Found. Crystallogr., 1990, 46, C34. 